University of Nebraska - Lincoln

DigitalCommons@University of Nebraska - Lincoln

2013

\title{
Simulated yield and profitability of five potential crops for intensifying the dryland wheat-fallow production system
}

\author{
S. A. Saseendran \\ USDA-ARS
}

David C. Nielsen

USDA-ARS, Akron, CO, dcnielsen55@gmail.com

\section{L.R. Ahuja}

Agricultural Systems Research Unit, USDA-ARS, Fort Collins, CO

L. Ma

USDA-ARS, Fort Collins, CO, Liwang.ma@ars.usda.gov

Drew J. Lyon

University of Nebraska-Lincoln, drew.lyon@wsu.edu

Follow this and additional works at: https://digitalcommons.unl.edu/panhandleresext

Saseendran, S. A.; Nielsen, David C.; Ahuja, L.R.; Ma, L.; and Lyon, Drew J., "Simulated yield and profitability of five potential crops for intensifying the dryland wheat-fallow production system" (2013). Panhandle Research and Extension Center. 64.

https://digitalcommons.unl.edu/panhandleresext/64

This Article is brought to you for free and open access by the Agricultural Research Division of IANR at DigitalCommons@University of Nebraska - Lincoln. It has been accepted for inclusion in Panhandle Research and Extension Center by an authorized administrator of DigitalCommons@University of Nebraska - Lincoln. 


\title{
Simulated yield and profitability of five potential crops for intensifying the dryland wheat-fallow production system
}

\author{
S.A. Saseendran ${ }^{\mathrm{a}}$, D.C. Nielsen ${ }^{\text {b, } *}$, L.R. Ahuja ${ }^{\mathrm{a}}$, L. $\mathrm{Ma}^{\mathrm{a}}$, D.J. Lyon ${ }^{\mathrm{c}}$ \\ a Agricultural Systems Research Unit, USDA-ARS, Fort Collins, CO 80526, United States \\ b Central Great Plains Research Station, USDA-ARS, 40335 County Road GG, Akron, CO 80720, United States \\ ' University of Nebraska, Panhandle Res. E' Ext. Ctr., 4502 Ave. I, Scottsbluff, NE 69361, United States
}

\section{A R T I C L E I N F O}

\section{Article history:}

Received 6 March 2012

Accepted 24 July 2012

Available online 9 August 2012

\section{Keywords:}

Crop simulation

Soil water

Modeling

RZWQM2

DSSAT

Soil water

Triticale

Canola

Millet

Corn

\begin{abstract}
A B S T R A C T
Greater precipitation use efficiency (PUE) and economic returns by increasing cropping frequency through the addition of summer crops to the dryland winter wheat-fallow (WF) cropping system have been reported in the semiarid Central Great Plains of USA. However, due to the highly variable nature of precipitation and uncertain water availability, selection of a crop with assured positive net returns to add to the system to increase cropping frequency is a challenge in the absence of reliable seasonal precipitation forecasts. The objective of this study was to evaluate long-term yields and net returns of several potential summer crops at various soil water contents at planting to assess their potential use in increasing dryland cropping frequency. Three grain crops [corn (Zea mays L.), canola (Brassica napus), and proso millet (Panicum miliaceum L.)] and two forage crops [foxtail millet (Setaria italica L. Beauv.) and spring triticale (X Triticosecale rimpaui Wittm.)] for which the Root Zone Water Quality Model (RZWQM2) had been calibrated at Akron, $\mathrm{CO}$ and/or Sidney, NE, were selected for investigation through modeling. The calibrated model was used to simulate yield responses of the crops to $25,50,75$ and $100 \%$ of plant available water (PAW) in the soil profile at planting using recorded weather data from Akron, CO and Sidney, NE (1948-2008). Average costs of production and 10-yr average commodity prices for northeast Colorado were used to calculate net returns for each of the crops at the varying PAW levels. All crops showed significant $(p<0.05)$ simulated yield increases in response to increasing initial PAW levels when those changes occurred in the entire $0-180 \mathrm{~cm}$ soil profile. The two forage crops gave greater net returns than the three grain crops for all initial PAW levels when calculated with 10-yr average prices received. Among the grain crops, proso millet was slightly more profitable than corn at Akron, while corn was the least profitable crop at Sidney. Using current commodity prices (13 September 2011) resulted in proso millet being the least profitable crop at Sidney, while corn was the most profitable grain crop at Akron and showed net returns that were similar to those found for the forage crops. The results of this study may guide the selection of a spring- or summer-planted crop and help farmers assess risk as they contemplate intensifying the WF system by using a measure or estimate of PAW at planting.
\end{abstract}

Published by Elsevier B.V.

\section{Introduction}

Successful dryland agricultural production in semiarid areas requires efficient utilization of the variable precipitation for crop water use (Nielsen et al., 2005). In the semiarid Central Great Plains of the USA, nearly $80 \%$ of the annual precipitation is received during the spring and summer months from April to September. Fallowing the tilled field between wheat crops (about 14 months) has been a widely used soil management practice to increase PAW at planting and reduce variability in crop yields (Greb, 1979; Nielsen and Calderón, 2011; Tanaka and Anderson, 1997). However, even

\footnotetext{
* Corrresponding author. Tel.: +1 970345 0507; fax: +1 9703452088 .

E-mail address: david.nielsen@ars.usda.gov (D.C. Nielsen).
}

with no-till management an average of only $35 \%$ of the precipitation received during the fallow period in this region is stored for use by the next crop (Nielsen and Vigil, 2010). Precipitation received in the two-year period of a WF rotation (average values of $831 \mathrm{~mm}$ at Akron, Colorado and $846 \mathrm{~mm}$ at Sidney, Nebraska) on average supplies more water than a single wheat crop can use. Consequently the potential exists to crop more frequently than once every two years. The economics of intensifying cropping frequency can be positively affected because of the increased income from an additional crop (Lyon et al., 2004). The conventionally tilled WF system has also often been cited as a cause for severe soil erosion and soil quality degradation in the region (Black, 1983; Anderson, 1998; Bowman et al., 1990, 1999; Dhuyvetter et al., 1996; Nielsen and Calderón, 2011; Norwood et al., 1990; Peterson and Westfall, 2004). Hence, for both economic improvement and water and soil 
conservation reasons, much research has been focused on cropping system intensification to reduce fallow frequency, resulting in recommendations for several crop rotations and no-tillage practices (Acosta-Martınez et al., 2007; Anderson et al., 1999; Halvorson, 1990; Nielsen, 1998; Peterson et al., 1993; Vigil and Nielsen, 1998).

Intensification of the WF system with summer crops such as corn, grain sorghum, and proso millet, especially under no-till practices, has been reported to provide higher annualized yield and overall production than WF over multiple years (Peterson et al., 1993, 1996; Halvorson et al., 2002; Peterson and Westfall, 2004). Nielsen et al. (2002) showed that inserting corn or proso millet into the WF rotation (i.e., WCF or WMF) did not significantly affect soil water content at wheat planting or lower wheat yields. Winter triticale (with water use efficiency of $16.5 \mathrm{~kg} \mathrm{ha}^{-1} \mathrm{~mm}^{-1}$ ) and foxtail millet (with water use efficiency of $14.3 \mathrm{~kg} \mathrm{ha}^{-1} \mathrm{~mm}^{-1}$ ) were reported to be efficient forage crops for the High Plains region (Nielsen et al., 2006). Recently, interest in spring-planted canola as a potential oilseed crop for the Central Great Plains of the USA has increased due to its use as a potential feedstock in biodiesel production (Minor and Meinke, 1990; Pavlista and Baltensperger, 2007).

The right choice of a summer crop may vary from year-toyear and location-to-location due to the variable and unpredictable nature of precipitation in the Great Plains (Dhuyvetter et al., 1996; Nielsen et al., 1999, 2002; Nielsen and Vigil, 2005). A challenge currently faced by farmers is to choose a profitable spring or summer crop without a reliable seasonal weather forecast and location-specific long-term data that reflect and incorporate the uncertainties in net returns due to the climate variability at the location. Weisensel et al. (1991) analyzed relative riskiness in net returns from alternative cropping strategies in Saskatchewan, Canada and concluded that flexible cropping based on PAW in the soil at planting can be the most profitable cropping strategy. The use of PAW in the soil during spring has been suggested as a way to determine whether to summer fallow or plant a short-duration crop prior to winter wheat seeding in the fall (Felter et al., 2006; Lyon et al., 1995, 2004, 2007; Nielsen et al., 2010). However, these short-term field experiments may not be transferrable beyond the experimental years. System models are needed to extend these short-term results to multiple years using location specific longterm weather data (Jame and Cutforth, 1996; Saseendran et al., 2004, 2005a; Elliott and Cole, 1989; Mathews et al., 2002). Model simulation can provide farmers with information on the probability of yield and economic return from potential crop choices in response to variable weather (especially precipitation) conditions.

Therefore, our objectives were to (1) use the calibrated and validated crop models within RZWQM2 along with observed long-term daily weather data to study the yield responses of three grain crops (corn, canola, and proso millet), and two forage crops (foxtail millet and spring triticale) to four levels of PAW at planting $(25,50$, 75 and $100 \%$ ) and varying weather conditions at Akron, Colorado, and Sidney, Nebraska and (2) develop and compare probabilities of production and net returns from crop selections based on PAW at planting at these locations.

\section{Materials and methods}

\subsection{Site characteristics}

Locations for the study were (1) the USDA-ARS Central Great Plains Research Station $\left(40^{\circ} 09^{\prime} \mathrm{N}, 103^{\circ} 09^{\prime} \mathrm{W}, 1383 \mathrm{~m}\right.$ elevation above sea level) located near Akron, CO and (2) the University of Nebraska High Plains Agricultural Laboratory $\left(41^{\circ} 12^{\prime} \mathrm{N}, 103^{\circ} 00^{\prime} \mathrm{W}\right.$, 1315 m elevation above sea level) located near Sidney, NE. The soil type at Akron was a Weld silt loam (fine, smectitic, mesic Aridic
Argiustolls) with a pH of 7.0 and organic matter content of about $15 \mathrm{~g} \mathrm{~kg}^{-1}$ in the surface $15 \mathrm{~cm}$. The soil type at Sidney was a Keith silt loam (fine-silty, mixed, superactive, mesic Aridic Argiustolls) with a $\mathrm{pH}$ of 7.0 and an organic matter content of approximately $20 \mathrm{~g} \mathrm{~kg}^{-1}$ in the surface $15 \mathrm{~cm}$. Detailed soil properties used for input into the model were reported earlier (Saseendran et al., 2008, 2009, 2010a). Uniform field capacity $\left(0.2855 \mathrm{~m}^{3} \mathrm{~m}^{-3}\right)$ and wilting point $\left(0.1361 \mathrm{~m}^{3} \mathrm{~m}^{-3}\right)$ were assumed to exist through the entire $0-180 \mathrm{~cm}$ soil profile at both locations, resulting in a maximum PAW of $269 \mathrm{~mm}$.

Typical growing seasons for summer crops planted in this region are May to September for corn, April to July for canola, June to September for proso millet, June to August for foxtail millet, and April to June for spring triticale (Table 1) (Lyon et al., 2004). Weather records (61 years, 1948-2008) for both Akron and Sidney were used in the study to represent climate variability. The data showed that the mean growing season precipitation for grain corn, canola, and proso millet, and forage foxtail millet and spring triticale ranged between $170 \mathrm{~mm}$ and $296 \mathrm{~mm}$ (Table 1). The low amount of precipitation received during the crop growth period requires that crops grown at these locations use stored soil water to meet evapotranspirational demand (Nielsen et al., 1999, 2002; Nielsen and Vigil, 2005). On average, Sidney recorded slightly more precipitation than Akron during the corn $(7 \mathrm{~mm})$, canola $(15 \mathrm{~mm})$, proso millet $(8 \mathrm{~mm})$, and foxtail millet ( $3 \mathrm{~mm})$ growing seasons, and triticale $(21 \mathrm{~mm})$ growing seasons. Average temperatures at Sidney are consistently lower than at Akron.

\subsection{RZWQM2 Model}

The Root Zone Water Quality Model (RZWQM2) is a processoriented agricultural system model that integrates the physical, chemical and biological processes for simulation of the impact of tillage, residue cover, water, fertilizers, and crop management practices on crop production and water quality (Ahuja et al., 2000; Ma et al., 2009). In addition to a generic crop model that can be parameterized to simulate specific crops, it contains the CSM (Cropping System Models) crop modules of DSSAT 4.0 (Decision Support System for Agrotechnology Transfer) (Ma et al., 2005, 2006, 2009; Hoogenboom et al., 1999; Jones et al., 2003) (http://arsagsoftware.ars.usda.gov/agsoftware/). A number of studies verifying the potential of applying RZWQM2 for managing dryland cropping systems in the Great Plains have been reported (Ma et al., 2003; Saseendran et al., 2004, 2005a,b, 2008, 2009). Most recently, Saseendran et al. (2010a) used RZWQM2 to successfully model 14-17 years of data on several dryland crop rotations involving corn, winter wheat, and proso millet under no-tillage at Akron, CO. Their modeling results for corn grain yield are shown in Fig. 1.

Saseendran et al. (2010b) adapted the CSM-CROPGRO model for simulation of spring canola in both RZWQM2 and DSSAT 4.0. The model was parameterized, calibrated, and validated for simulation of the crop using data from canola irrigation experiments conducted on the Weld silt loam soil at Akron, Colorado during 1993, 1994, 2005, and 2006. Their modeling results for canola grain yield are shown in Fig. 1.

Felter et al. (2006) reported a two-year study on yield responses of proso millet (grain), spring triticale (forage), and foxtail millet (forage) to a range of soil water levels at planting at Akron, CO and Sidney, NE. Using the data collected in these experiments, Saseendran et al. (2009) developed crop modules for simulation of those three crops within RZWQM2 using CSM-CERES v 4.0 modules and successfully modeled the experiments at both locations using the same set of parameters that were calibrated for one location (Akron). The results of those modeling efforts are also shown in Fig. 1. 

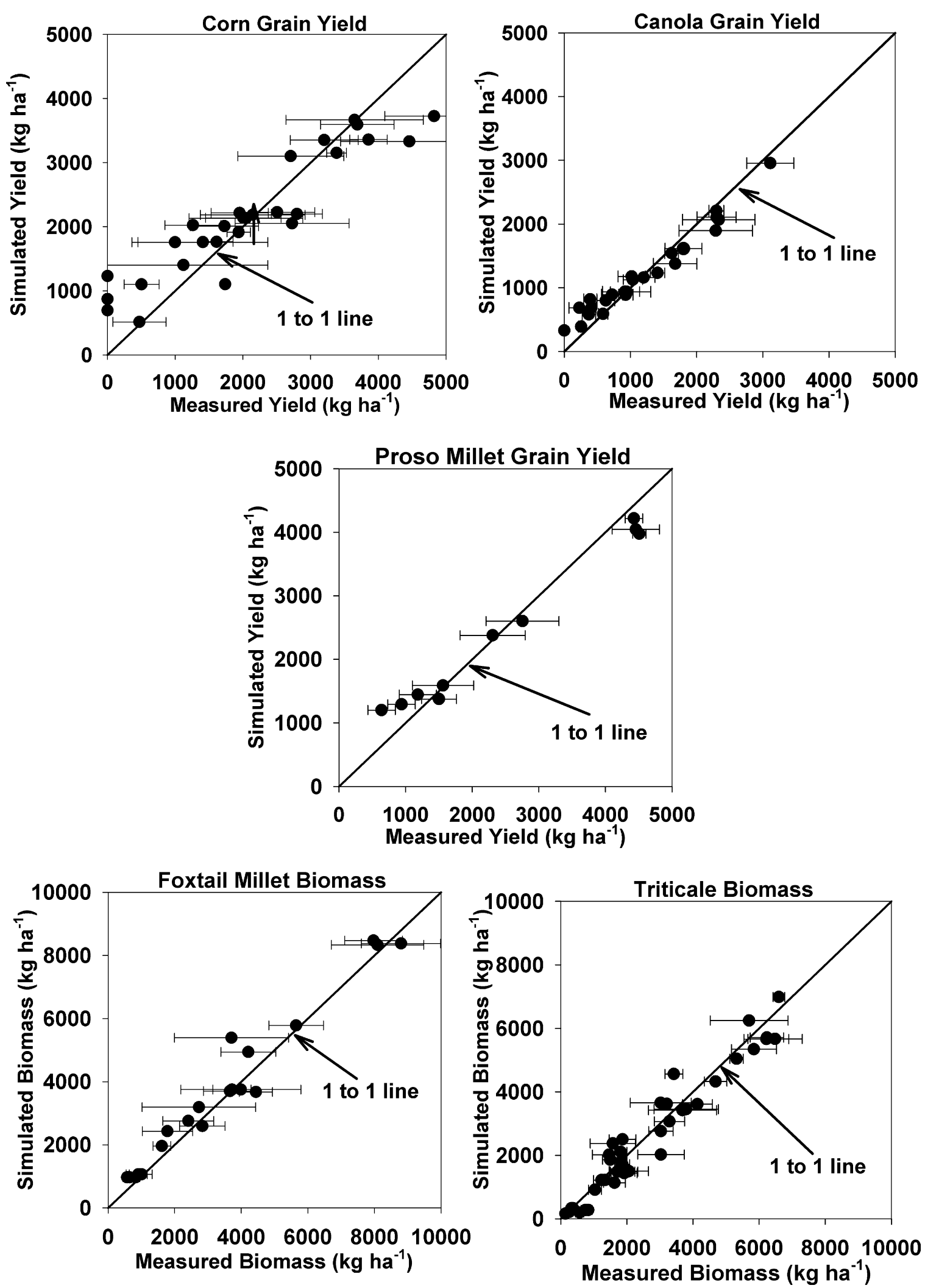

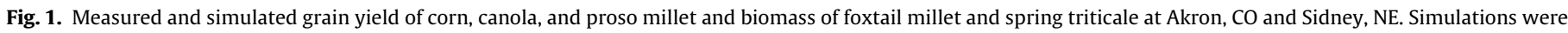

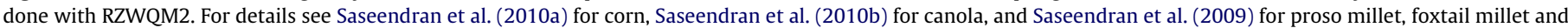
spring triticale. 
Table 1

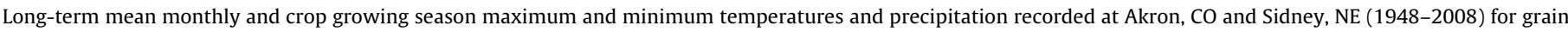
corn, canola, and proso millet, and forage foxtail millet and spring triticale crops.

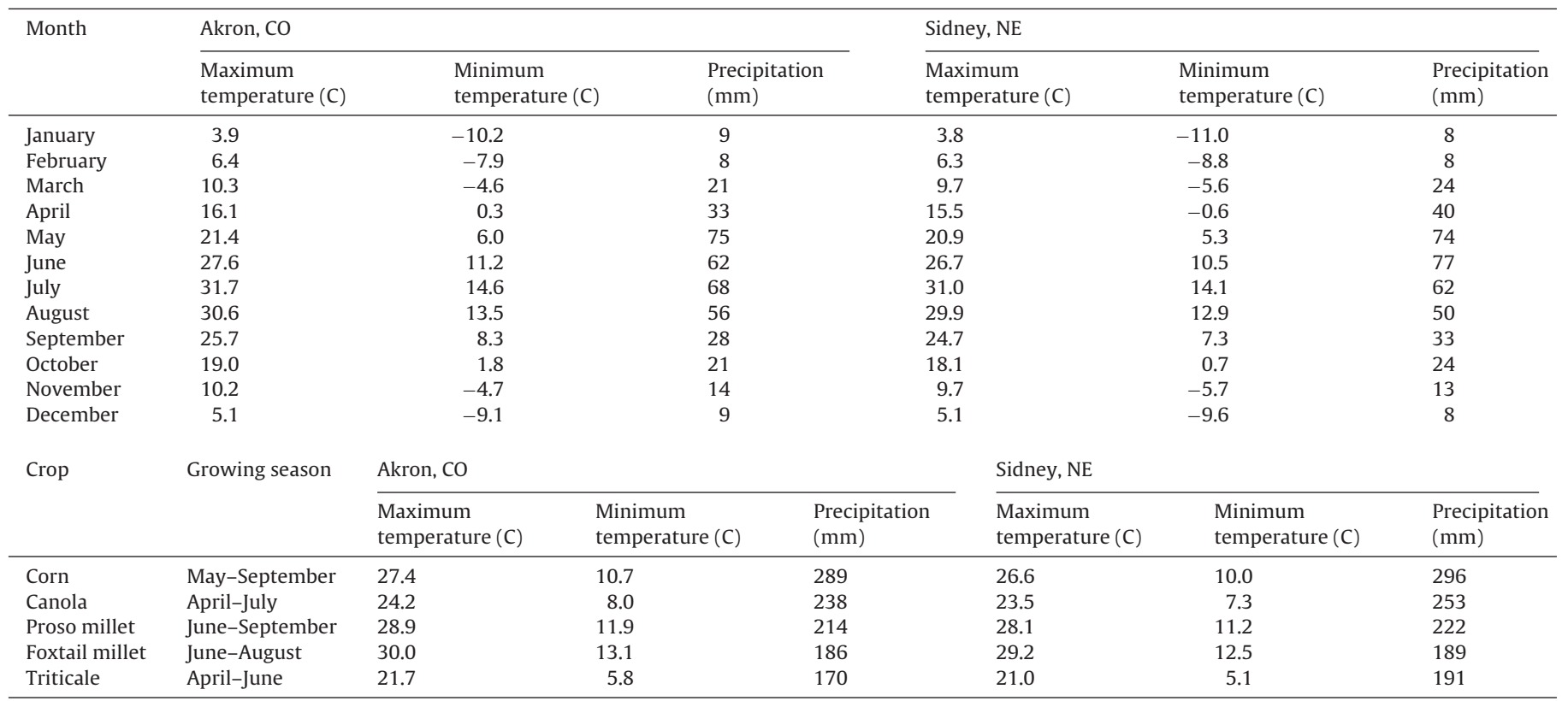

The modules for corn and canola were not separately validated for simulations at Sidney, NE. However, based on the successful modeling of grain proso millet and forage triticale and foxtail millet responses to PAW at planting at both Akron and Sidney using the parameters that were developed for one location (Akron) by Saseendran et al. (2009), we assumed that the modules for corn and canola varieties parameterized for Akron were applicable to Sidney as well.

\subsection{Long-term simulations of crop responses to PAW at planting}

All long-term simulations were conducted using weather data collected from 1948 to 2008 (61 years) at both locations. However, solar radiation and wind speed data were available only from 1983 through 2008. The solar radiation and wind speed data records were extended backward to 1948 using the WGEN weather generator utility available in DSSAT (Richardson, 1985; Jones et al., 2003). Whenever relative humidity data were missing in the climate records, they were estimated using the RZWQM2 utility for calculation of relative humidity from maximum and minimum air temperature data (Ahuja et al., 2000). Simulated crops under notillage were planted every crop season on the same day of the year with the same initial soil water levels (soil moisture reset at planting) and soil-fertilizer-crop management practices typical for the region (Table 2 ) such that the only variables in the simulations were the weather recorded at these locations during the crop growing seasons.

A soil profile depth of $180 \mathrm{~cm}$ was assumed in the simulations. However, taking into account the uncertainty in soil water changes in the whole profile in response to the limited precipitation received in the region, we investigated crop responses to (1) variable PAW at planting in the whole soil profile (WP, $0-180 \mathrm{~cm}$ ) and (2) variable PAW at planting only in the top $45 \mathrm{~cm}$ of the soil profile while assuming the water content in the bottom $135 \mathrm{~cm}$ of the profile to be at a uniform initial level of $50 \%$ of the maximum possible PAW (TP). The average soil water condition in this region on 1 May following wheat production with no-till management of the crop residue is about 70\% PAW as shown by Nielsen and Vigil (2010), but is highly variable from year to year depending on non-crop period precipitation. Additionally, conventional tillage of the residue during the non-crop period results in lower PAW in the spring, hence the need to acquire yield simulation results over a range of PAW at planting. Total available soil water contents in a $180 \mathrm{~cm}$ soil profile under the WP scenario were $67,135,202$ and $269 \mathrm{~mm}$ and under the TP scenario were 118, 135, 151 and $168 \mathrm{~mm}$, respectively, at the $25 \%, 50 \%, 75 \%$ and $100 \%$ PAW levels at planting. Averaged over the four PAW levels, the $180-\mathrm{cm}$ soil profile under the WP scenario held $17.7 \%$ more PAW than under the TP scenario. Simulations of crop yield responses to PAW at planting in both WP and TP scenarios were made. All simulated yield responses to various PAWs at planting under the WP and TP scenarios were analyzed for treatment differences in mean grain yields $(p<0.05)$ by one-way analysis of variance (Dowdy and Wearden, 1991).

Simulated crop yields in response to $25,50,75$, and 100\% PAW at planting were plotted as cumulative distribution function (CDF) curves for each crop. The CDF curves represent the fraction of years when the yield was at least the given value. Separate curves were developed assuming PAW changes under WP and TP scenarios. The same information is also presented as box plots depicting mean and median, and 5, 10, 25, 75, 90, and 95 percentiles of crop yields simulated in response to the four PAW levels at planting to assess average yield and variability of yield for each of the five crops at the two locations.

Net farming returns in response to crop choices based on PAW at planting in the above scenarios were calculated from simulated crop yields, historical average crop prices (1992-2001) for northeast Colorado obtained from the National Agricultural Statistics Service of the United States Department of Agriculture, and costs of production of these crops also from northeast Colorado (Table 3) (Nielsen et al., 2010). Because of the very large increases in commodity prices that have occurred in recent years, net farming returns were also calculated using the same simulated yields and costs of production, but with current (13 September 2011) prices being received in northeast Colorado for the five crops simulated in this study. For each PAW level at planting, net returns for different crops were compared using box plots. These box plots can serve as a decision support tool for assessing risk regarding net economic return when making a crop selection based on various levels of PAW at planting. 
Table 2

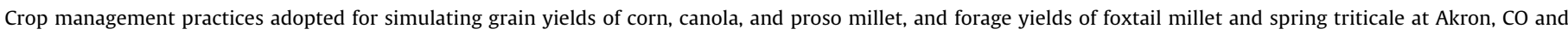
Sidney, NE.

\begin{tabular}{|c|c|c|c|c|c|c|}
\hline Crop & Cultivar & Planting density (seeds ha ${ }^{-1}$ ) & Planting date & Row spacing $(\mathrm{cm})$ & $N\left(\mathrm{~kg} \mathrm{ha}^{-1}\right)$ & Harvest date \\
\hline Corn & NK4242BT & 35,000 & May 19 & 76 & 67 & Simulated \\
\hline Canola & Westar/Hyola & 630,000 & April 08 & 19 & 67 & Simulated \\
\hline Proso millet & Huntsman & $2,810,000$ & June 13 & 25 & 67 & Simulated \\
\hline Forage foxtail millet & White Wonder & $5,300,000$ & June 13 & 25 & 67 & August 30 \\
\hline Forage triticale & Trical 2700 & $2,580,000$ & April 05 & 25 & 67 & June 25 \\
\hline
\end{tabular}

\section{Results and discussion}

\subsection{Crop responses to PAW in the whole profile (WP)}

In our long-term simulations at both Akron and Sidney with initial soil water variations in the whole profile (WP), corn, canola and proso millet grain yields, and triticale and foxtail millet forage yields increased significantly $(p<0.05)$ in response to all four PAW levels at planting in all years (Figs. 2-6 and Table 4 ). The model simulated a higher probability of obtaining at least a given grain yield with increasing initial PAW level. For example, for corn grown at Akron a grain yield of at least $3763 \mathrm{~kg} \mathrm{ha}^{-1}$ (the breakeven yield identified by Nielsen et al., 2010) would be expected $17 \%$ of the time with initial PAW of $25 \%$ and $86 \%$ of the time with initial PAW at $100 \%$ (Fig. 2a). Average grain yields (reported at a moisture content of $0.155 \mathrm{~g} \mathrm{~g}^{-1}$ ) simulated at Akron in response to the four PAW levels at planting were between $2679 \mathrm{~kg} \mathrm{ha}^{-1}\left(\mathrm{SD}=1259 \mathrm{~kg} \mathrm{ha}^{-1}\right)$ and $5803 \mathrm{~kg} \mathrm{ha}^{-1}\left(\mathrm{SD}=1649 \mathrm{~kg} \mathrm{ha}^{-1}\right)$, respectively (Fig. $2 \mathrm{~b}$ and Table 4). Corresponding mean grain yields simulated for Sidney were between $2416 \mathrm{~kg} \mathrm{ha}^{-1}\left(\mathrm{SD}=1183 \mathrm{~kg} \mathrm{ha}^{-1}\right)$ and $4140 \mathrm{~kg} \mathrm{ha}^{-1}$ $\left(\mathrm{SD}=1460 \mathrm{~kg} \mathrm{ha}^{-1}\right)$ (Fig. $2 \mathrm{~d}$ and Table 4$)$. The probability of obtaining at least a yield of $3763 \mathrm{~kg} \mathrm{ha}^{-1}$ at Sidney was $10 \%$ of the time with initial PAW of $25 \%$ and $59 \%$ of the time with initial PAW of 100\% (Fig. 2c).

The probability of achieving at least the breakeven canola yield of $1120 \mathrm{~kg} \mathrm{ha}^{-1}$, as designated by Nielsen et al. (2010), was $26 \%$ of the time with $25 \%$ PAW increasing to $91 \%$ of the time with $100 \%$ PAW at Akron under the WP scenario (Fig. 3a). Mean canola grain yields (reported at a moisture content of $0.10 \mathrm{~g} \mathrm{~g}^{-1}$ ) simulated at Akron increased with increasing PAW at planting from $882 \mathrm{~kg} \mathrm{ha}^{-1}$ $\left(\mathrm{SD}=510 \mathrm{~kg} \mathrm{ha}^{-1}\right)$ to $1779 \mathrm{~kg} \mathrm{ha}^{-1}\left(\mathrm{SD}=431 \mathrm{~kg} \mathrm{ha}^{-1}\right)$ (Fig. $3 \mathrm{~b}$ and Table 4). Mean grain yields simulated at Sidney varied between $975 \mathrm{~kg} \mathrm{ha}^{-1}\left(\mathrm{SD}=475 \mathrm{~kg} \mathrm{ha}^{-1}\right)$ and $1775 \mathrm{~kg} \mathrm{ha}^{-1}\left(\mathrm{SD}=324 \mathrm{~kg} \mathrm{ha}^{-1}\right)$
(Fig. 3d and Table 4). Uncertainty in yields, due to inter-annual weather variability, as reflected in the range or spread of percentile distributions (5 and 95 percentiles) of simulated long-term grain yields, in the box plots decreased with increasing initial PAW at Akron but not at Sidney (Fig. 3b and d).

Delgado et al. (2000) reported an average root depth at harvest of $76 \mathrm{~cm}$ for canola grown on loamy sands and sandy loams in south-central Colorado. In the current simulations, we had about $80 \%$ of the root distribution to this depth. With a shallow rooting depth, less stored soil water is available to the crop for consumptive use and this may explain the lower response of canola to increasing PAW compared with corn (Fig. 3 vs. Fig. 2). Additionally, a C3, oil-producing species such as canola will have a much lower response to water availability than a $\mathrm{C} 4$ species such as corn (Fisher and Turner, 1978; Hanks, 1983; Nielsen et al., 2005). Nielsen et al. (2010) reported that the corn grain yield response to water use was 3.33 times the canola grain yield response to water use. We found the simulated response of corn grain yield to soil water availability at Akron to be 3.48 times the canola response $\left(15.47 \mathrm{~kg} \mathrm{ha}^{-1} \mathrm{~mm}^{-1}\right.$ vs. $\left.4.44 \mathrm{~kg} \mathrm{ha}^{-1} \mathrm{~mm}^{-1}\right)$. At Sidney corn grain yield response to PAW was only 2.35 times greater than the canola response $\left(12.43 \mathrm{~kg} \mathrm{ha}^{-1} \mathrm{~mm}^{-1}\right.$ vs. $\left.5.30 \mathrm{~kg} \mathrm{ha}^{-1} \mathrm{~mm}^{-1}\right)$. The lower response of corn to PAW at Sidney compared with corn at Akron is likely a result of differences in rainfall distribution between the two locations. Akron averaged 10\% greater precipitation in July and August than Sidney (Table 1). Nielsen et al. (2009) showed how the response of dryland corn grain yield to PAW at planting increased with increasing amount of precipitation between 15 July and 25 August. Additionally, the cooler and wetter conditions during the canola growing season at Sidney compared with Akron (Table 1) likely resulted in the increased yield response of canola to soil water at planting at Sidney relative to Akron.

Table 3

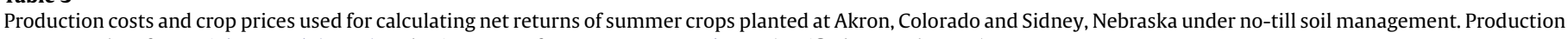
costs are taken from Nielsen et al. (2010) and prices come from www.nass.usda.gov (verified 1 March 2010).

\begin{tabular}{|c|c|c|c|c|c|}
\hline \multirow[t]{2}{*}{ Operation } & \multicolumn{5}{|l|}{ Costs } \\
\hline & Corn & Canola & Proso millet & Forage foxtail millet & Forage triticale \\
\hline Planting (\$/ha) & 24.70 & 22.30 & 22.30 & 22.30 & 22.30 \\
\hline Seed $(\$ /$ ha $)$ & 48.13 & 5.62 & 0.26 & 0.26 & 0.26 \\
\hline Spraying (\$/ha) & 12.97 & 12.97 & 12.97 & 12.97 & 12.97 \\
\hline Glyphosate (\$/ha) & 12.35 & 12.35 & 12.35 & 12.35 & 12.35 \\
\hline Fertilizer N (\$/ha) & 54.94 & 54.94 & 54.94 & 54.94 & 54.94 \\
\hline Fertilizer P $(\$ /$ ha $)$ & 7.14 & 7.14 & 7.14 & 7.14 & 7.14 \\
\hline Swathing (\$/ha) & 0.00 & 19.76 & 19.76 & 24.70 & 24.70 \\
\hline $\begin{array}{l}\text { Harvesting ( } \$ / \text { ha) } \\
\text { (if corn or proso millet yield exceeds } \\
1254 \mathrm{~kg} \mathrm{ha}^{-1} \text {, additional cost of } \$ 2.07 \\
\text { per } 1000 \mathrm{~kg} \mathrm{ha}^{-1} \text { ) } \\
\text { (if canola yield exceeds } 1120 \mathrm{~kg} \mathrm{ha}^{-1} \text {, } \\
\text { additional cost of } \$ 2.32 \text { per } \\
1000 \mathrm{~kg} \mathrm{ha}^{-1} \text { ) }\end{array}$ & 32.11 & 32.11 & 32.11 & 32.11 & 32.11 \\
\hline Baling hay $(\$ / \mathrm{T})^{\mathrm{a}}$ & 0.00 & 0.00 & 0.00 & 14.70 & 14.70 \\
\hline Hauling $(\$ / \mathrm{T})^{\mathrm{a}}$ & 2.07 & 5.51 & 2.07 & 3.23 & 3.23 \\
\hline Average crop price, $1992-2001\left(\$ \mathrm{~kg}^{-1}\right)$ & 0.0941 & 0.2147 & 0.127 & 0.0937 & 0.0937 \\
\hline Crop price, 13 September $2011\left(\$ \mathrm{~kg}^{-1}\right)$ & 0.2831 & 0.5580 & 0.2701 & 0.1653 & 0.1653 \\
\hline
\end{tabular}

\footnotetext{
a Forage baling and hauling charges assume hay at $12 \%$ moisture. Hay hauling charges (Edwards, 2007) assume a 20 mile loaded distance.
} 

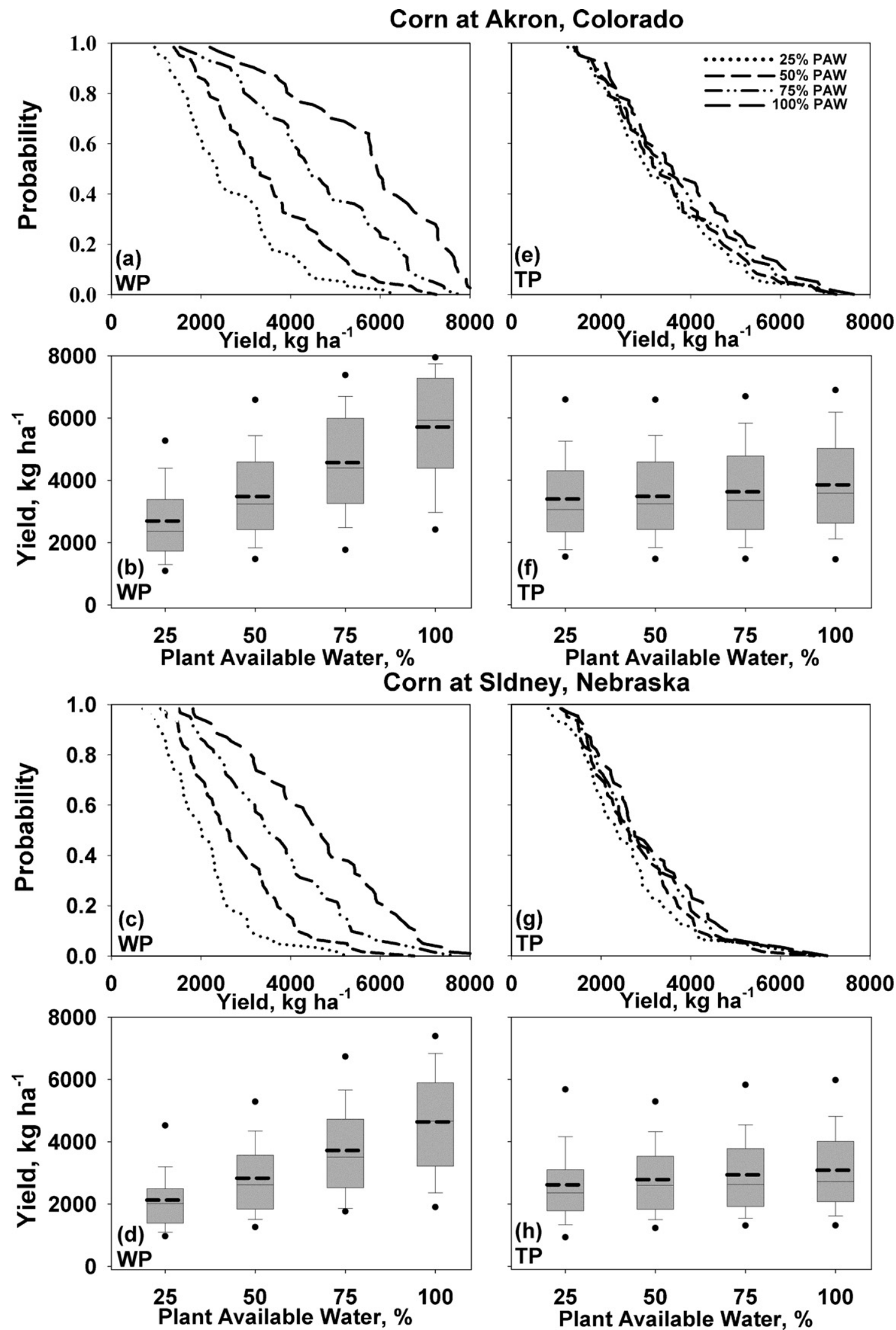

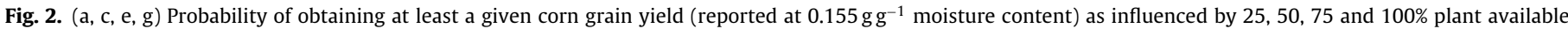

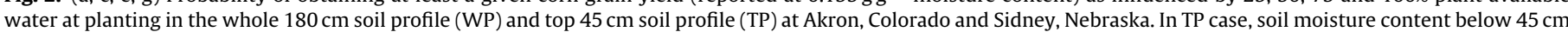

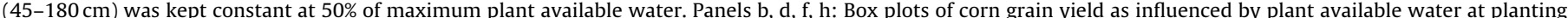

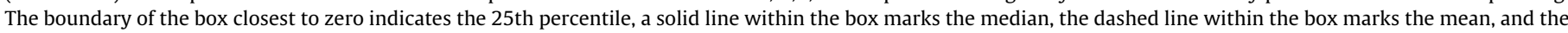

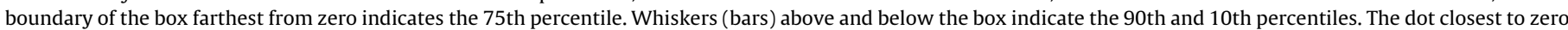
indicates the 5th percentile and farthest from zero indicates the 95th percentile. 

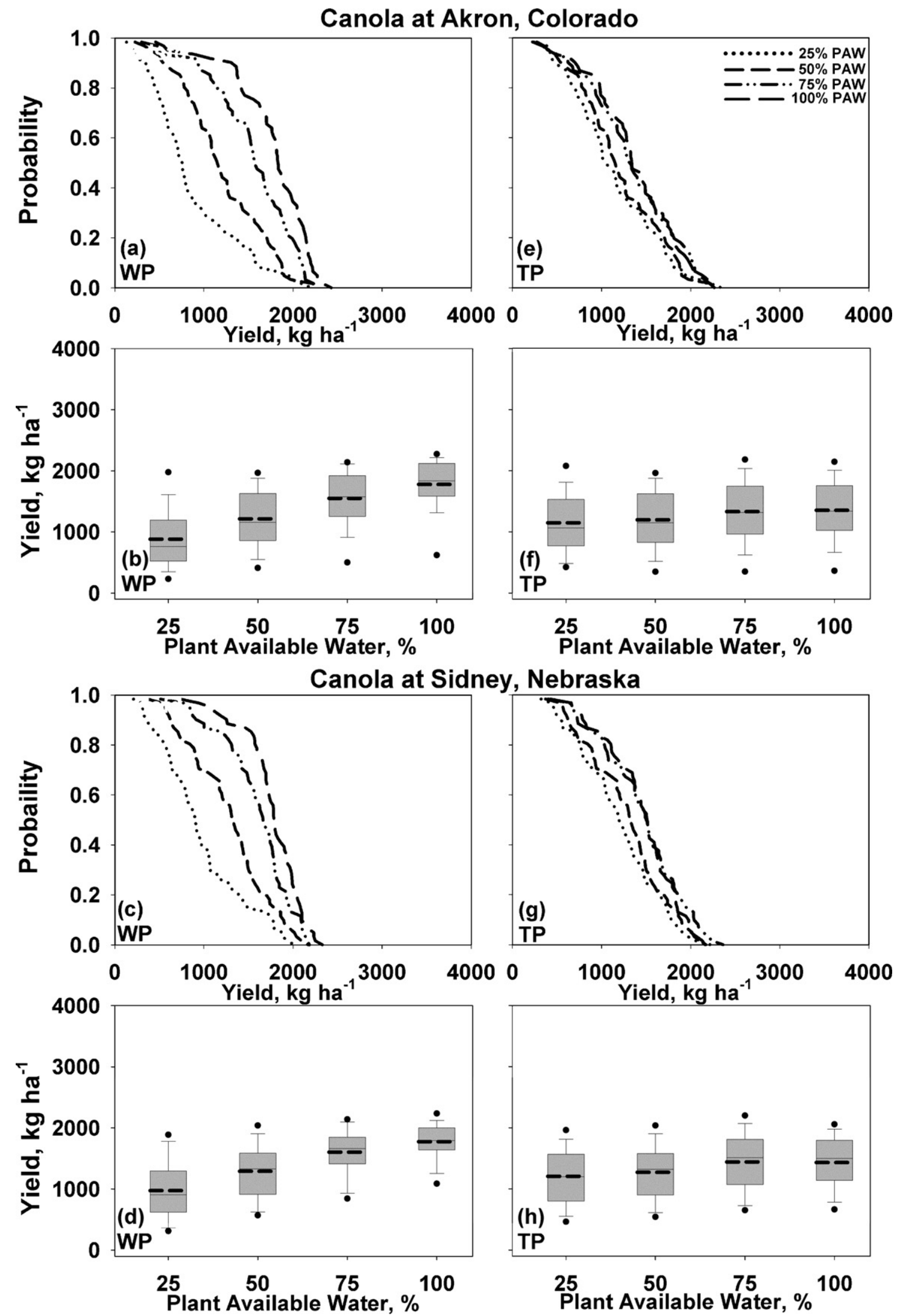

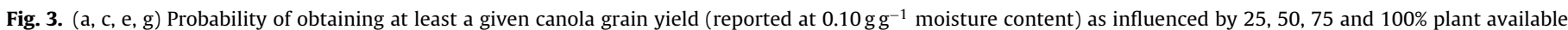

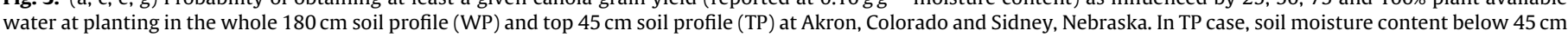

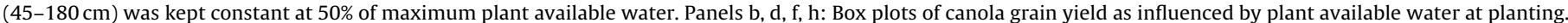

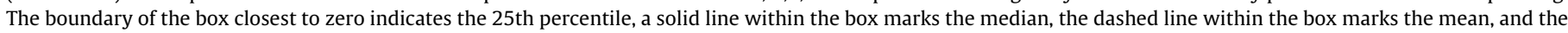

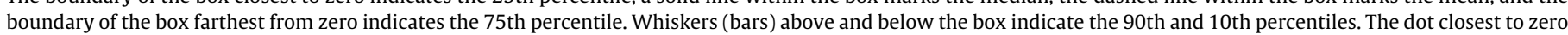
indicates the 5 th percentile and farthest from zero indicates the 95th percentile. 


\section{Proso millet at Akron, Colorado}
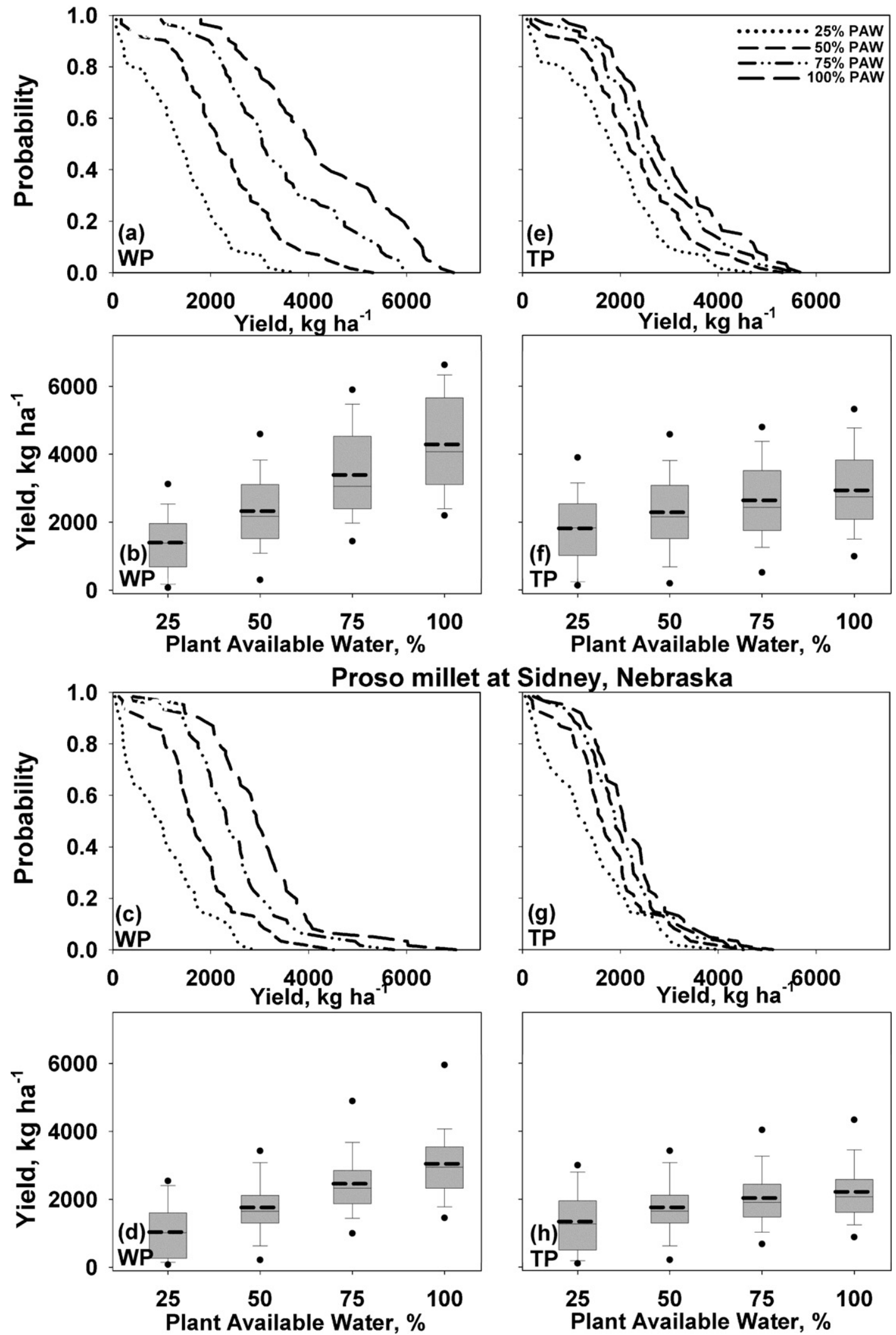

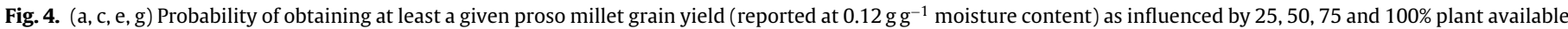

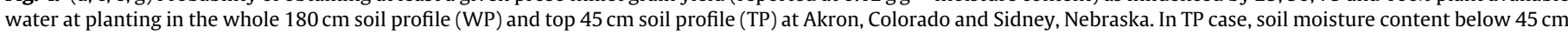

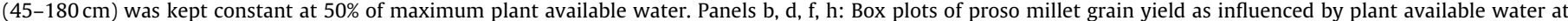

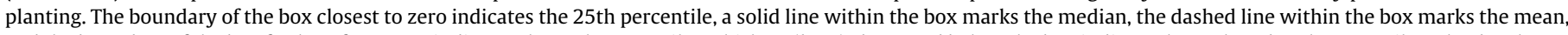

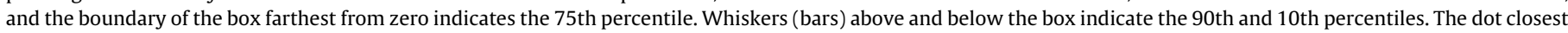
to zero indicates the 5 th percentile and farthest from zero indicates the 95th percentile. 


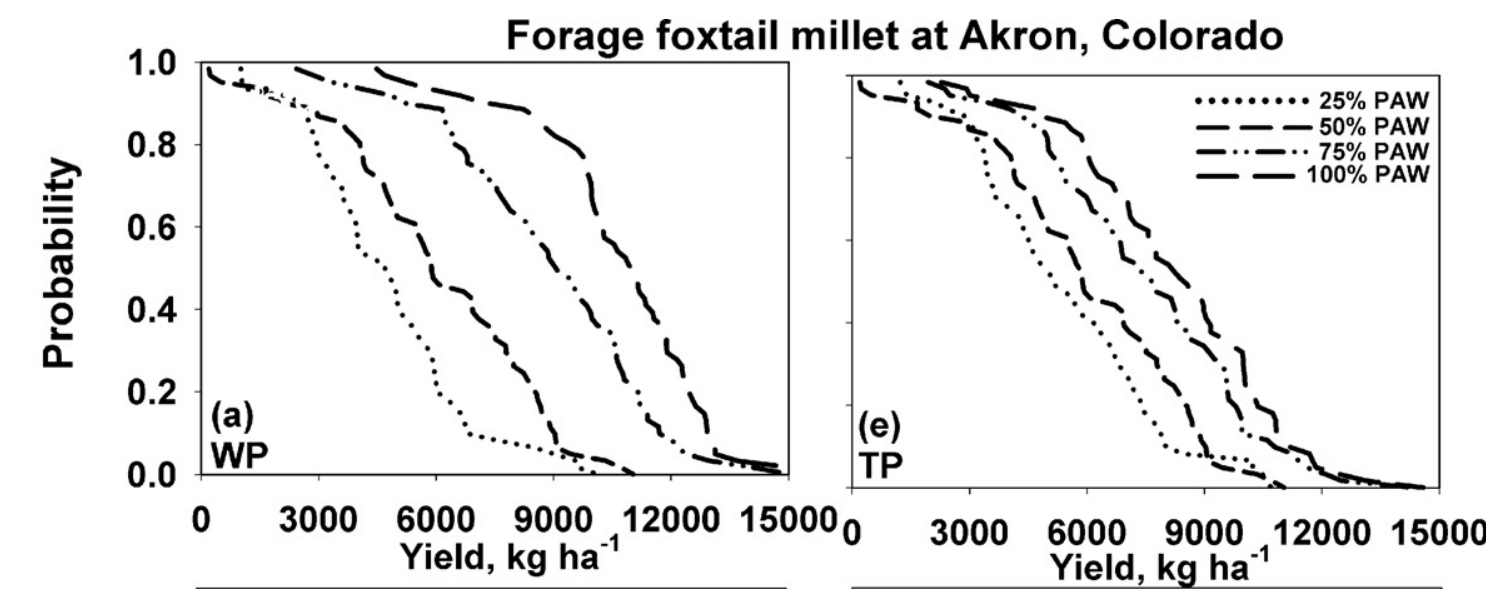

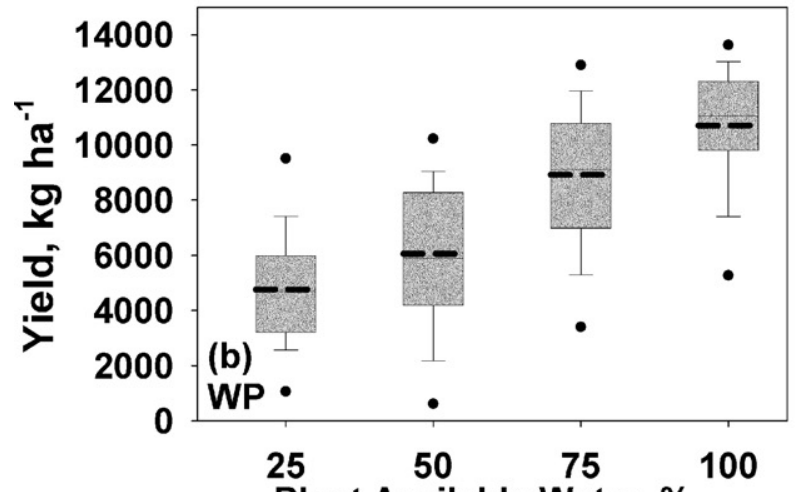

Plant Available Water, \%

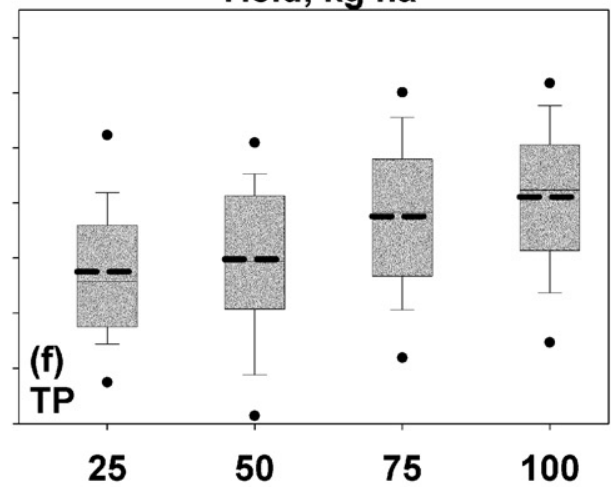

Plant Available Water, \%

Forage foxtail millet at Sidney, Nebraska
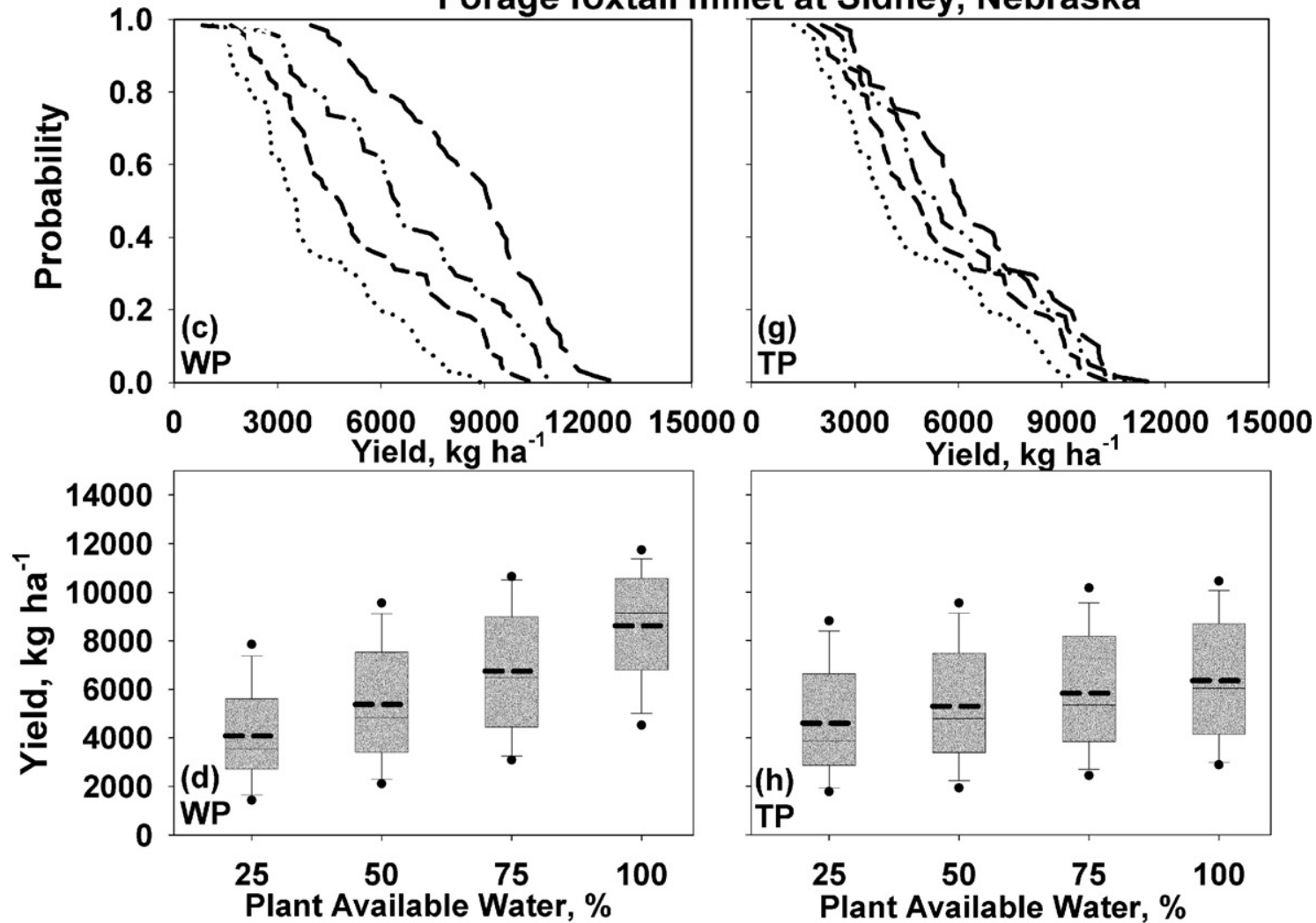

Plant Available Water, \%

Fig. 5. (a, c, e, g) Probability of obtaining at least a given foxtail millet forage yield (reported at $0.12 \mathrm{gg}^{-1}$ moisture content) as influenced by $25,50,75$ and $100 \%$ plant available water at planting in the whole $180 \mathrm{~cm}$ soil profile (WP) and top $45 \mathrm{~cm}$ soil profile (TP) at Akron, Colorado and Sidney, Nebraska. In TP case, soil moisture content below $45 \mathrm{~cm}(45-180 \mathrm{~cm})$ was kept constant at $50 \%$ of maximum plant available water. Panels b, d, f, h: Box plots of foxtail millet forage yield as influenced by plant available water at planting. The boundary of the box closest to zero indicates the 25th percentile, a solid line within the box marks the median, the dashed line within the box marks the mean, and the boundary of the box farthest from zero indicates the 75th percentile. Whiskers (bars) above and below the box indicate the 90th and 10th percentiles. The dot closest to zero indicates the 5th percentile and farthest from zero indicates the 95th percentile. 

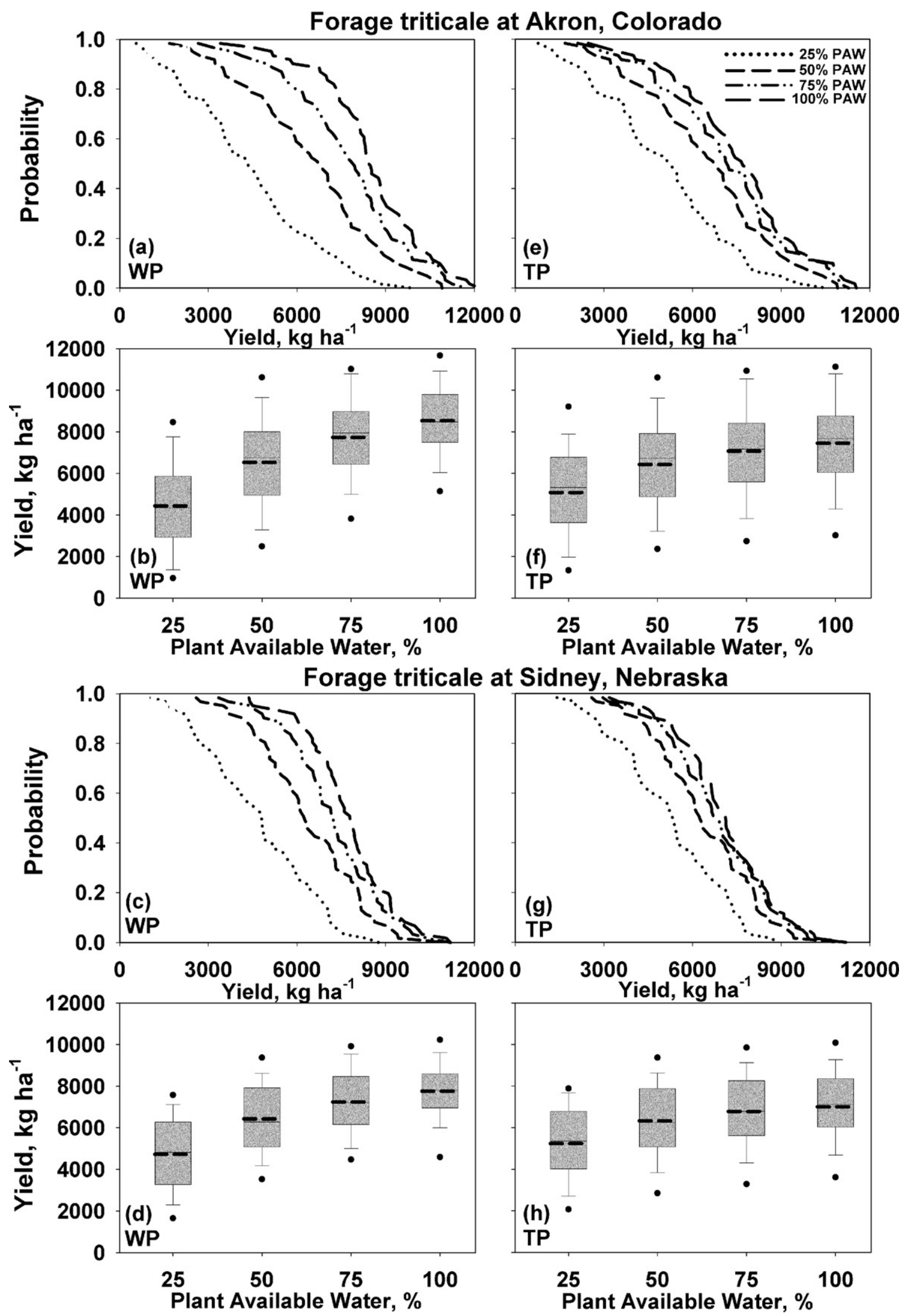

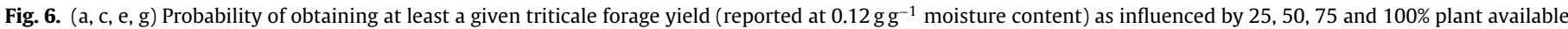

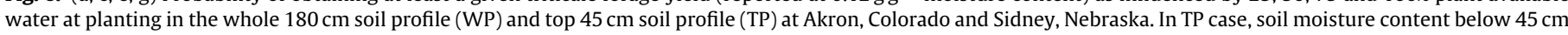

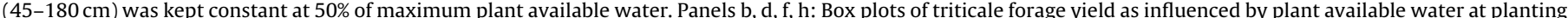

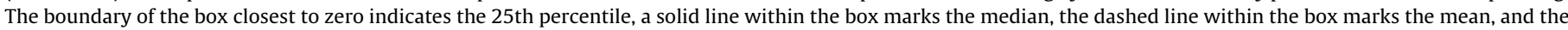

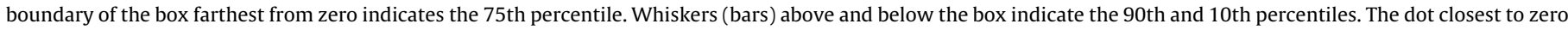
indicates the 5th percentile and farthest from zero indicates the 95th percentile. 


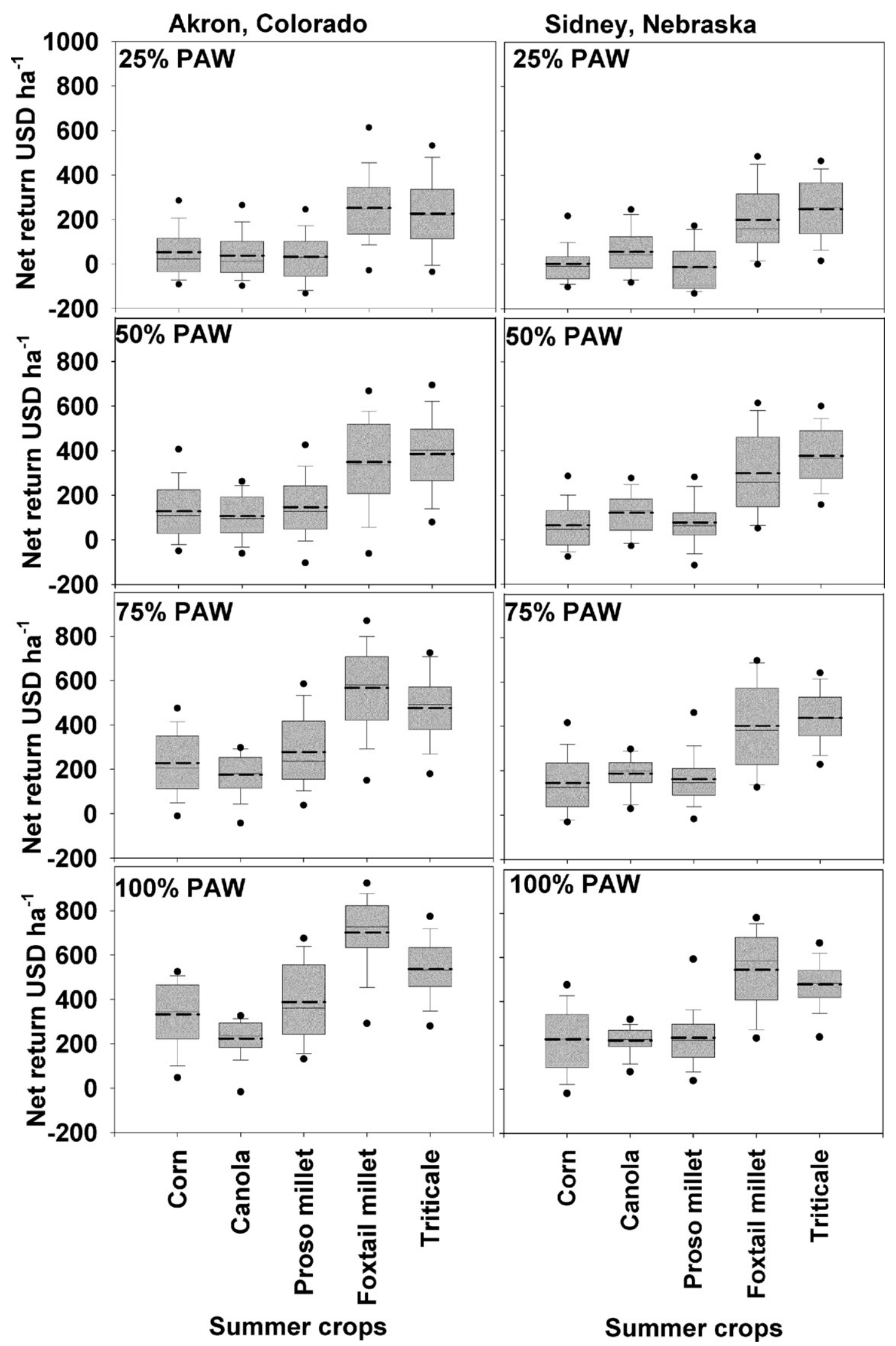

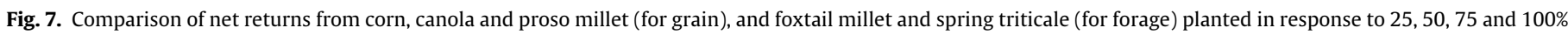

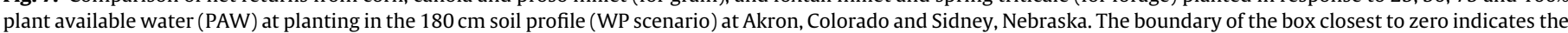

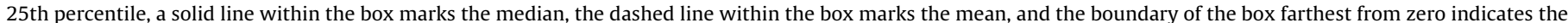

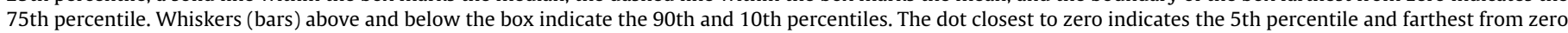

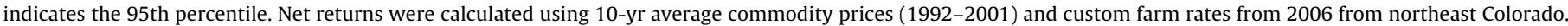
USD = US dollars 
Table 4

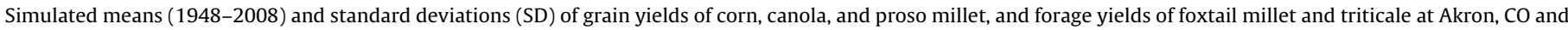

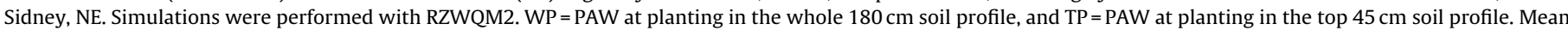

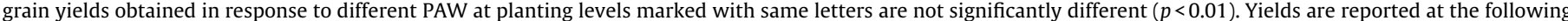
moisture contents: corn $\left(0.155 \mathrm{~g} \mathrm{~g}^{-1}\right)$; canola $\left(0.100 \mathrm{~g} \mathrm{~g}^{-1}\right)$; proso millet $\left(0.120 \mathrm{~g} \mathrm{~g}^{-1}\right)$; foxtail millet $\left(0.120 \mathrm{~g} \mathrm{~g}^{-1}\right)$; triticale $\left(0.120 \mathrm{~g} \mathrm{~g}^{-1}\right)$.

\begin{tabular}{|c|c|c|c|c|c|c|c|c|}
\hline \multirow[t]{4}{*}{ Crop } & \multicolumn{8}{|c|}{ PAW at planting (\%) } \\
\hline & 25 & 50 & 75 & 100 & 25 & 50 & 75 & 100 \\
\hline & \multicolumn{8}{|l|}{$\mathrm{kg} \mathrm{ha}^{-1}$} \\
\hline & \multicolumn{4}{|c|}{ Akron - WP } & \multicolumn{2}{|c|}{ Sidney - WP } & & \\
\hline \multicolumn{9}{|l|}{ Corn } \\
\hline Mean & $2679 a^{a}$ & $3537 b$ & $4646 c$ & $5803 d$ & 2129a & $2828 b$ & $3722 c$ & $4640 d$ \\
\hline SD & 1259 & 1422 & 1604 & 1649 & 952 & 1193 & 1459 & 1631 \\
\hline \multicolumn{9}{|l|}{ Canola } \\
\hline Mean & $882 \mathrm{a}$ & $1215 b$ & $1551 c$ & 1779d & $975 a$ & $1292 b$ & $1603 c$ & $1775 d$ \\
\hline SD & 510 & 484 & 466 & 431 & 475 & 451 & 386 & 324 \\
\hline \multicolumn{9}{|c|}{ Proso millet } \\
\hline Mean & $1401 \mathrm{a}$ & $2326 b$ & $3392 c$ & 4289d & $1036 a$ & $1762 b$ & $2457 c$ & $3046 d$ \\
\hline SD & 895 & 1128 & 1315 & 1445 & 795 & 898 & 1002 & 1145 \\
\hline \multicolumn{9}{|c|}{ Foxtail millet } \\
\hline Mean & $4762 a$ & $6057 b$ & $8921 c$ & 10707d & $4082 a$ & $5383 b$ & $6747 c$ & $8622 d$ \\
\hline SD & 2090 & 2598 & 2656 & 2266 & 2073 & 2506 & 2592 & 2309 \\
\hline \multicolumn{9}{|l|}{ Triticale } \\
\hline Mean & $4439 a$ & $6532 b$ & $7734 \mathrm{c}$ & $8535 c$ & $4725 a$ & $6428 b$ & $7240 c$ & $7756 c$ \\
\hline SD & 2242 & 2275 & 2041 & 1765 & 1875 & 1778 & 1616 & 1456 \\
\hline \multirow[t]{4}{*}{ Crop } & \multicolumn{8}{|c|}{ PAW at planting (\%) } \\
\hline & 25 & 50 & 75 & 100 & 25 & 50 & 75 & 100 \\
\hline & \multicolumn{8}{|l|}{$\mathrm{kg} \mathrm{ha}^{-1}$} \\
\hline & \multicolumn{3}{|c|}{ Akron - TP } & & \multicolumn{2}{|c|}{ Sidney - TP } & & \\
\hline \multicolumn{9}{|l|}{ Corn } \\
\hline Mean & $3395 a$ & $3537 a$ & $3688 a$ & $3915 a$ & $2617 a$ & $2828 b$ & $2983 c$ & $3185 c$ \\
\hline SD & 1391 & 1422 & 1483 & 1575 & 1241 & 1193 & 1272 & 1319 \\
\hline \multicolumn{9}{|l|}{ Canola } \\
\hline Mean & $1148 a$ & $1215 a$ & $1351 a$ & $1375 a$ & $1206 a$ & $1292 b$ & $1464 c$ & $1455 c$ \\
\hline SD & 493 & 484 & 508 & 479 & 461 & 451 & 461 & 408 \\
\hline \multicolumn{9}{|c|}{ Proso millet } \\
\hline Mean & $1817 a$ & $2326 a b$ & $2683 b c$ & $2982 c$ & $1340 a$ & $1762 b$ & $2033 c$ & $2219 d$ \\
\hline SD & 1087 & 1128 & 1143 & 1174 & 939 & 898 & 889 & 912 \\
\hline \multicolumn{9}{|c|}{ Foxtail millet } \\
\hline Mean & $5515 a$ & $6057 a$ & $7635 b$ & $8353 b$ & $4600 a$ & $5383 b$ & $5929 c$ & $6454 d$ \\
\hline SD & 2372 & 2598 & 2643 & 2571 & 2349 & 2506 & 2504 & 2479 \\
\hline \multicolumn{9}{|l|}{ Triticale } \\
\hline Mean & $5074 a$ & $6532 b$ & $7179 b c$ & $7569 c$ & 5239a & $6427 b$ & $6885 c$ & $7112 c$ \\
\hline SD & 2284 & 2275 & 2202 & 2111 & 1828 & 1778 & 1725 & 1653 \\
\hline
\end{tabular}

a Means with the same letter within the same row and water profile treatment scenario (WP or TP) are not different as tested by Tukey's HSD ( $p$ : 0.05).

As with corn and canola, the probability for obtaining at least the breakeven proso millet grain yield of $2016 \mathrm{~kg} \mathrm{ha}^{-1}$ at Akron (Nielsen et al., 2010) increased from 21\% of the time at $25 \%$ PAW to $96 \%$ of the time at $100 \%$ PAW (Fig. 4a). Average grain yields (reported at a moisture content of $0.12 \mathrm{~g} \mathrm{~g}^{-1}$ ) simulated at Akron ranged from $1401\left(\mathrm{SD}=895 \mathrm{~kg} \mathrm{ha}^{-1}\right)$ to $4289 \mathrm{~kg} \mathrm{ha}^{-1}$ $\left(\mathrm{SD}=1445 \mathrm{~kg} \mathrm{ha}^{-1}\right)$ (Fig. $4 \mathrm{~b}$ and Table 4$)$. Owing to the high variability in the growing season (June to September) precipitation amounts at the location, the simulated grain yields also exhibited high inter-annual variability as depicted in the difference between the 5 and 95 percentile points in Fig. 4b. Average proso millet grain yield increase with each $25 \%$ increase in initial PAW at Akron was $963 \mathrm{~kg} \mathrm{ha}^{-1}$. Simulated mean proso millet grain yields at Sidney increased in response to increasing PAW at planting from 1036 $\left(\mathrm{SD}=795 \mathrm{~kg} \mathrm{ha}^{-1}\right)$ to $3046 \mathrm{~kg} \mathrm{ha}^{-1}\left(\mathrm{SD}=1145 \mathrm{~kg} \mathrm{ha}^{-1}\right)$ (Fig. $7 \mathrm{~d}$ and $\mathrm{h}$ and Table 4 ). Average yield gain with each $25 \%$ increase in initial PAW was $670 \mathrm{~kg} \mathrm{ha}^{-1}$.

At Akron, the probability of obtaining at least the breakeven foxtail millet forage yield of $4768 \mathrm{~kg} \mathrm{ha}^{-1}$ (Nielsen et al., 2010) was $48 \%$ of the time at $25 \%$ PAW and $97 \%$ of the time at $100 \%$ PAW (Fig. 5a). The forage yields (reported at a moisture content of $0.12 \mathrm{~g} \mathrm{~g}^{-1}$ ) simulated in response to the four PAW at planting levels were between $4762\left(\mathrm{SD}=2090 \mathrm{~kg} \mathrm{ha}^{-1}\right)$ and $10707 \mathrm{~kg} \mathrm{ha}^{-1}$ $\left(\mathrm{SD}=2266 \mathrm{~kg} \mathrm{ha}^{-1}\right)$ (Fig. 5b and Table 4). Forage yield of foxtail millet grown in a 2-yr study in the central Great Plains was reported to increase by $40 \mathrm{~kg} \mathrm{ha}^{-1}$ per mm of PAW at planting (Felter et al., 2006). The simulated forage yield response to PAW at planting was $29 \mathrm{~kg} \mathrm{ha}^{-1}$ per mm under the WP conditions. Inter-annual variability in forage yield only slightly decreased with increases in initial PAW, as reflected in the similar ranges of percentile distributions (spread along the vertical axis) in the box plots of Fig. 5b. In response to the four levels of PAW at planting at Sidney, average simulated foxtail millet forage yields increased from $4082\left(\mathrm{SD}=2073 \mathrm{~kg} \mathrm{ha}^{-1}\right)$ to $8622 \mathrm{~kg} \mathrm{ha}^{-1}\left(\mathrm{SD}=2309 \mathrm{~kg} \mathrm{ha}^{-1}\right.$ ) (Fig. 5d and Table 4).

At Akron, in response to the four PAW at planting levels, the model simulated mean triticale forage yields (reported at a moisture content of $\left.0.12 \mathrm{~g} \mathrm{~g}^{-1}\right)$ between $4439\left(\mathrm{SD}=2242 \mathrm{~kg} \mathrm{ha}^{-1}\right)$ and $8535 \mathrm{~kg} \mathrm{ha}^{-1}\left(\mathrm{SD}=1765 \mathrm{~kg} \mathrm{ha}^{-1}\right)$ (Fig. $6 \mathrm{~b}$ and Table 4$)$. The probability of obtaining at least the breakeven yield of $4768 \mathrm{~kg} \mathrm{ha}^{-1}$ (Nielsen et al., 2010) was $41 \%$ of the time at 25\% PAW increasing to $91 \%$ of the time at $100 \%$ PAW (Fig. 6a). Average forage yields simulated at Sidney increased from $4725\left(\mathrm{SD}=1875 \mathrm{~kg} \mathrm{ha}^{-1}\right)$ to $7756 \mathrm{~kg} \mathrm{ha}^{-1}\left(\mathrm{SD}=1456 \mathrm{~kg} \mathrm{ha}^{-1}\right)$ (Fig. 6d and Table 4). Felter et al. (2006) reported a similar increase in forage yield of 
triticale to increasing PAW at planting. They reported dry weights of about $1000 \mathrm{~kg} \mathrm{ha}^{-1}$ with $11 \%$ PAW at planting increasing to about $7000 \mathrm{~kg} \mathrm{ha}^{-1}$ with $89 \%$ PAW at planting.

\subsection{Crop responses to PAW in the top profile (TP)}

Under soil water variations only in the top $45 \mathrm{~cm}$ profile (TP), mean corn, canola and proso millet grain yields, and foxtail millet and triticale forage yields at both locations increased numerically in response to the four increasing PAW levels at planting, but those increases were not significant for corn and canola at Akron (Fig. 2e, g; 3e, g; 4e, g; 5e, g; and 6e, g) (Table 4). The probability of obtaining at least the breakeven corn grain yield of $3763 \mathrm{~kg} \mathrm{ha}^{-1}$ ranged from $0 \%$ (with 25\% PAW) to $41 \%$ (with 100\% PAW) at Akron and from $12 \%$ (with 25\% PAW) to $30 \%$ (with $100 \%$ PAW) at Sidney. Simulated average corn grain yields in response to PAW at planting variations were between $3395 \mathrm{~kg} \mathrm{ha}^{-1}\left(\mathrm{SD}=1391 \mathrm{~kg} \mathrm{ha}^{-1}\right)$ and $3915 \mathrm{~kg} \mathrm{ha}^{-1}\left(\mathrm{SD}=1575 \mathrm{~kg} \mathrm{ha}^{-1}\right)$ at Akron (Fig. 2f and Table 4), and between $2617 \mathrm{~kg} \mathrm{ha}^{-1}\left(\mathrm{SD}=1241 \mathrm{~kg} \mathrm{ha}^{-1}\right)$ and $3185 \mathrm{~kg} \mathrm{ha}^{-1}$ $\left(\mathrm{SD}=1319 \mathrm{~kg} \mathrm{ha}^{-1}\right)$ at Sidney (Fig. 2h, Table 4). A somewhat different situation was reported by Lyon et al. (1995). In their experiment with fairly uniform soil water contents at planting in the top $45 \mathrm{~cm}$ of the soil profile, but with widely varying soil water content at the lower depths, dryland corn grain yield was not well predicted by available soil water at planting. Our simulation results indicate that, in the case of corn, initial PAW influences grain yield when those differences in initial PAW occur throughout the whole $180 \mathrm{~cm}$ soil profile (assumed root zone). But if the water content at planting varies only in the TP $(45 \mathrm{~cm}$ soil profile, considered in the present study), simulations show that there was no major yield response. Nielsen et al. (2009) reported that the production functions derived from yield and soil water content at planting data for dryland corn grown in various crop-rotation sequences in the Great Plains were highly variable, with values ranging from 0.0 to $67.3 \mathrm{~kg} \mathrm{ha}^{-1}$ grain yield per mm of available soil water in the $0-180 \mathrm{~cm}$ soil profile at planting. The differences in yield response to soil water were attributed to the amount and timing of precipitation that fell during the critical reproductive and early grain-filling period. Our simulations indicate that the distribution of the soil water in the profile at planting may also be a factor.

In general, corn grain yield variability due to weather during the crop growing season, as depicted in the range or spread of simulated long-term yields in the box plots of Fig. 2 (differences in 5 and 95 percentiles of long-term simulations along the $y$-axis), did not decrease appreciably with increasing initial PAW at either Akron or Sidney under both the WP and TP scenarios (Fig. $2 \mathrm{f}$ and $\mathrm{h}$ ). This simulation result again confirms the observation that variability of corn grain yield is more influenced by growing season precipitation timing and amount than by soil water content at planting (Nielsen et al., 2009).

Mean canola grain yields simulated in response to the four PAW levels at planting were between $1148 \mathrm{~kg} \mathrm{ha}^{-1}\left(\mathrm{SD}=493 \mathrm{~kg} \mathrm{ha}^{-1}\right)$ and $1375 \mathrm{~kg} \mathrm{ha}^{-1}\left(\mathrm{SD}=479 \mathrm{~kg} \mathrm{ha}^{-1}\right)$ at Akron (Fig. 3f and Table 4). Average yield increase when increasing the PAW at planting from $25 \%$ to $50 \%$ in the TP was only $67 \mathrm{~kg} \mathrm{ha}^{-1}$. Mean grain yields simulated at Sidney varied between $1206 \mathrm{~kg} \mathrm{ha}^{-1}\left(\mathrm{SD}=461 \mathrm{~kg} \mathrm{ha}^{-1}\right)$ and $1455 \mathrm{~kg} \mathrm{ha}^{-1}\left(\mathrm{SD}=408 \mathrm{~kg} \mathrm{ha}^{-1}\right)$ (Fig. 3 h and Table 4$)$. At both Akron and Sidney, the variability in grain yield due to weather variability at all initial PAW levels in the TP remained more or less constant as reflected in the nearly identical vertical range (spread) of the percentile distributions shown in the box plots (Fig. 3f and h).

Simulated proso millet grain yields at Akron ranged from 1817 $\left(\mathrm{SD}=1087 \mathrm{~kg} \mathrm{ha}^{-1}\right)$ to $2982 \mathrm{~kg} \mathrm{ha}^{-1}\left(\mathrm{SD}=1174 \mathrm{~kg} \mathrm{ha}^{-1}\right)$ in response to the four PAW levels in the TP at planting (Fig. 4f and Table 4). Proso millet grain yields at Sidney increased in response to increasing PAW at planting from $1340\left(\mathrm{SD}=939 \mathrm{~kg} \mathrm{ha}^{-1}\right)$ to $2219 \mathrm{~kg} \mathrm{ha}^{-1}$
$\left(\mathrm{SD}=912 \mathrm{~kg} \mathrm{ha}^{-1}\right.$ ) (Fig. 4h and Table 4). Average yield increase with each $25 \%$ increase in initial PAW was $388 \mathrm{~kg} \mathrm{ha}^{-1}$ at Akron and $293 \mathrm{kgha}^{-1}$ at Sidney. These increases are equivalent to $23.3 \mathrm{~kg} \mathrm{ha}^{-1}$ (Akron) and $17.6 \mathrm{~kg} \mathrm{ha}^{-1}$ (Sidney) per mm of PAW at planting, which are much larger than the $8.3 \mathrm{~kg} \mathrm{ha}^{-1}$ per mm response reported by both Lyon et al. (1995) and Felter et al. (2006) from field studies with proso millet in which 79\% (Lyon et al., 1995) and 58\% (Felter et al., 2006) of the variation in grain yield was explained by variation in PAW at planting. Unpublished data from an analysis of 15 years of proso millet grain yield and water use data by D.C. Nielsen at Akron, Colorado indicated a greater yield response to water use $\left(23.4 \mathrm{~kg} \mathrm{ha}^{-1} \mathrm{~mm}^{-1}\right)$ than reported in previously published short-term field studies (Shanahan et al., 1988; Felter et al., 2006). Those greater yield responses occurred when precipitation in the middle of August was high, wind speed during the week prior to harvest was low (minimizing shattering losses), and daily maximum temperatures throughout the growing season rarely exceeded $36^{\circ} \mathrm{C}$. Hence greater yield response to PAW at planting from the long-term simulations compared with the 2yr field studies of Lyon et al. (1995) and Felter et al. (2006) is not unreasonable.

At Akron, average foxtail millet forage yields (reported at a moisture content of $0.12 \mathrm{~g} \mathrm{~g}^{-1}$ ) simulated in response to the four PAW at planting levels were between $5515\left(\mathrm{SD}=2372 \mathrm{~kg} \mathrm{ha}^{-1}\right)$ and $8353 \mathrm{~kg} \mathrm{ha}^{-1}\left(\mathrm{SD}=2571 \mathrm{~kg} \mathrm{ha}^{-1}\right)$ (Fig. $5 \mathrm{f}$ and Table 4). The simulated forage yield response to PAW was $57 \mathrm{~kg} \mathrm{ha}^{-1}$ per $\mathrm{mm}$, which was greater than the field-measured foxtail millet biomass response to soil water at planting $\left(40 \mathrm{~kg} \mathrm{ha}^{-1}\right.$ per $\left.\mathrm{mm}\right)$ reported by Felter et al. (2006). Under the TP scenario, inter-annual variability in forage yield did not decrease with increases in initial PAW, as reflected in the similar ranges of percentile distributions (spread along the vertical axis) in the box plots of Fig. 5f. Average foxtail millet forage yields simulated at Sidney were between 4600 $\left(\mathrm{SD}=2349 \mathrm{~kg} \mathrm{ha}^{-1}\right)$ and $6454 \mathrm{~kg} \mathrm{ha}^{-1}\left(\mathrm{SD}=2479 \mathrm{~kg} \mathrm{ha}^{-1}\right)$ (Fig. $5 \mathrm{~h}$ and Table 4).

At Akron, in response to the 25, 50, 75 and 100\% PAW at planting levels, the model simulated mean triticale forage yields (reported at a moisture content of $\left.0.12 \mathrm{~g} \mathrm{~g}^{-1}\right)$ between $5074\left(\mathrm{SD}=2284 \mathrm{~kg} \mathrm{ha}^{-1}\right)$ and $7569 \mathrm{~kg} \mathrm{ha}^{-1}\left(\mathrm{SD}=2111 \mathrm{~kg} \mathrm{ha}^{-1}\right)$ (Fig. $6 \mathrm{f}$ and Table 4). Average forage triticale yields simulated at Sidney increased from 5239 $\left(\mathrm{SD}=1828 \mathrm{~kg} \mathrm{ha}^{-1}\right)$ to $7112\left(\mathrm{SD}=1653 \mathrm{~kg} \mathrm{ha}^{-1}\right)$ in response to the four PAW levels at planting (Fig. 6h and Table 4).

\subsection{Net returns from plantings at various PAW levels in the whole profile (WP)}

In general, using the 2006 average production costs (Nielsen et al., 2010) and 10-yr average (1992-2001) grain and forage prices for northeast Colorado given in Table 4, the simulated long-term (61 yrs) net economic returns from all five crops increased significantly $(p<0.01)$ with increasing PAW at planting under the WP scenario (Fig. 7). At the 25\% PAW level, all five crops showed negative net dollar returns in some years. At this starting PAW at Akron, these negative returns were most frequent for corn and proso millet ( $43 \%$ of the crop seasons for both crops), followed by canola (39\% of the crop seasons), forage triticale ( $9 \%$ of the crop seasons) and forage foxtail millet ( $7 \%$ of the crop seasons). However, the number of negative return years decreased considerably with increases in PAW at planting. In general, for all five crops at both locations, when plantings were made with $75 \%$ or $100 \%$ PAW at planting, our simulations showed greater than $90 \%$ probability for positive net returns. In general, at both Akron and Sidney, average net return from crops planted in response to all PAW levels at planting were much higher for the forage crops (foxtail millet and triticale) than for the grain crops (corn, canola, and proso millet) (Fig. 7). For instance, average 


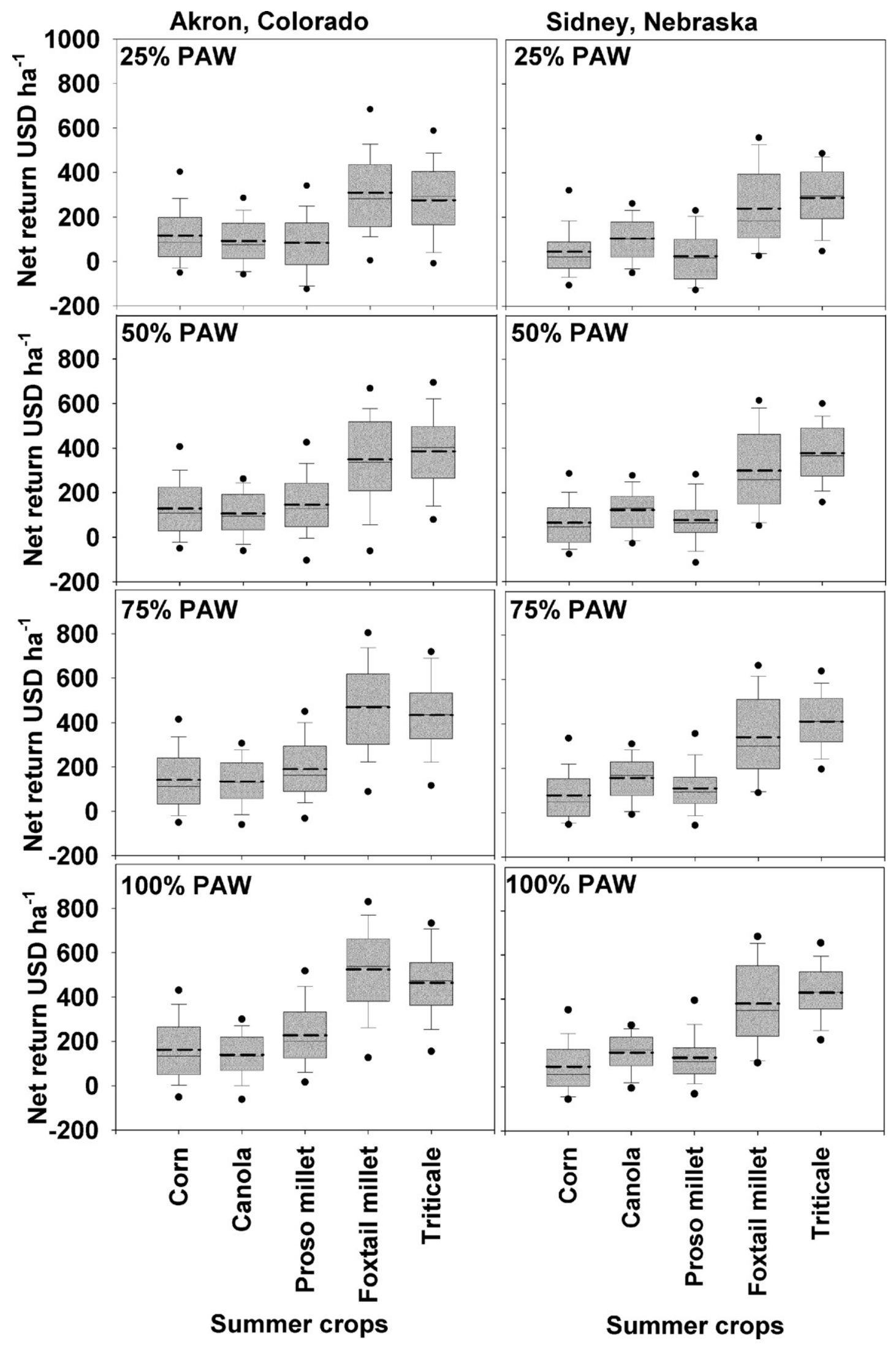

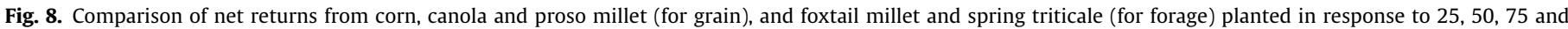

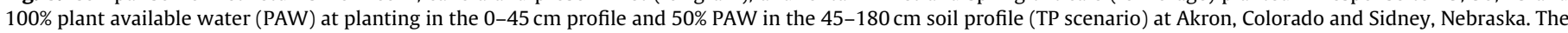

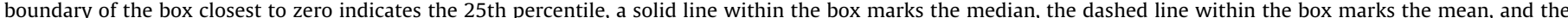

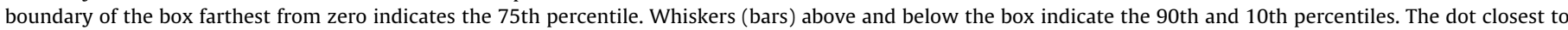

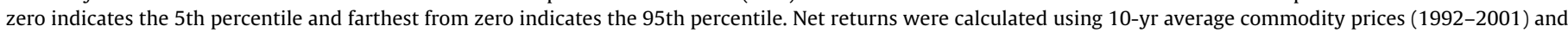
custom farm rates from 2006 from northeast Colorado. USD = US dollars. 


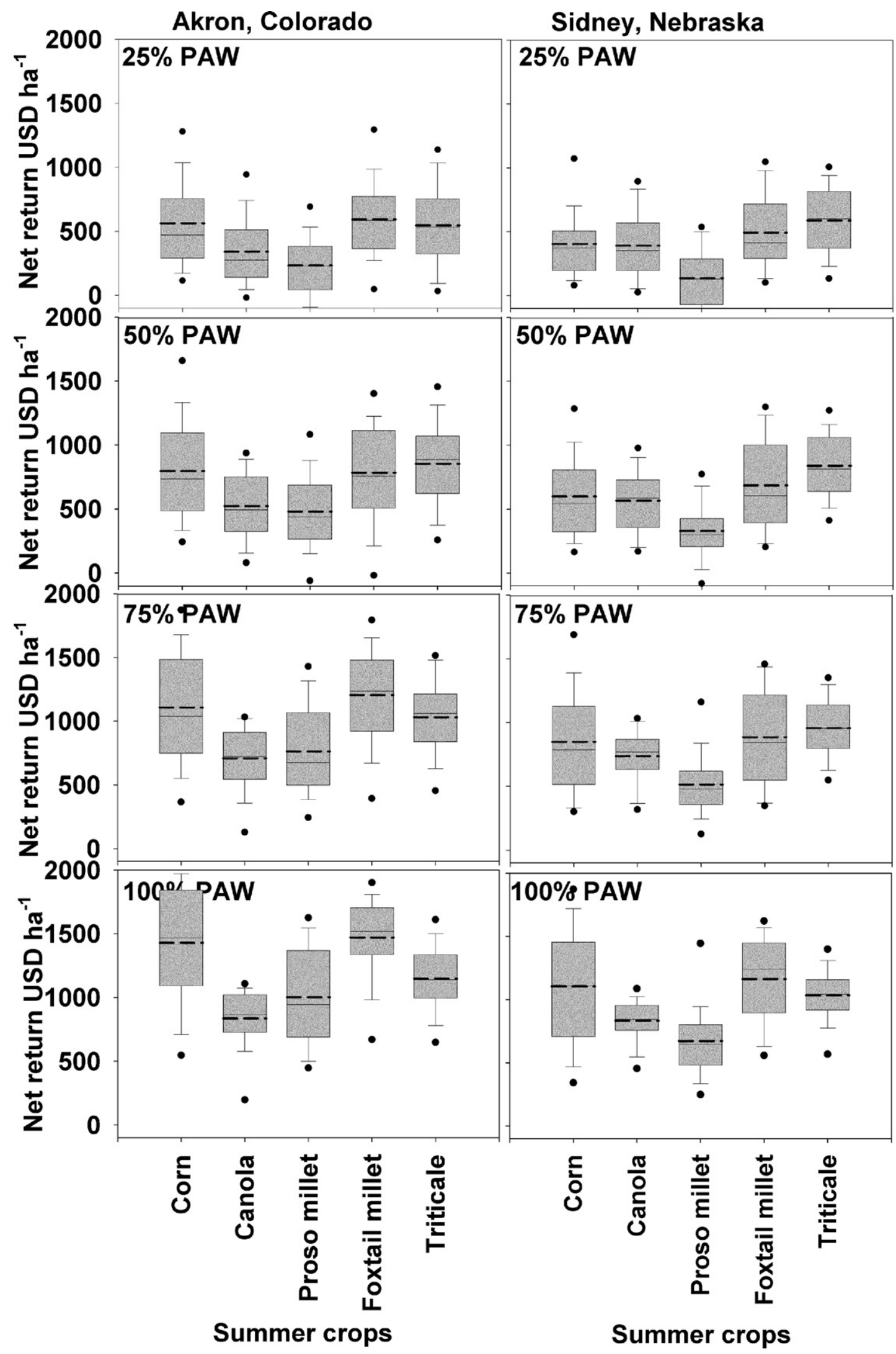

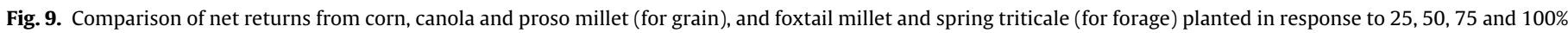

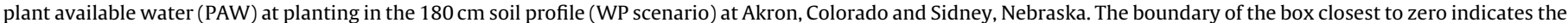

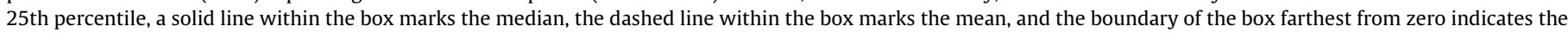

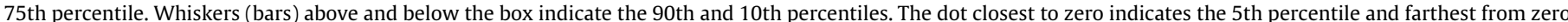

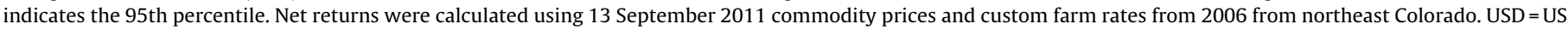
dollars. 


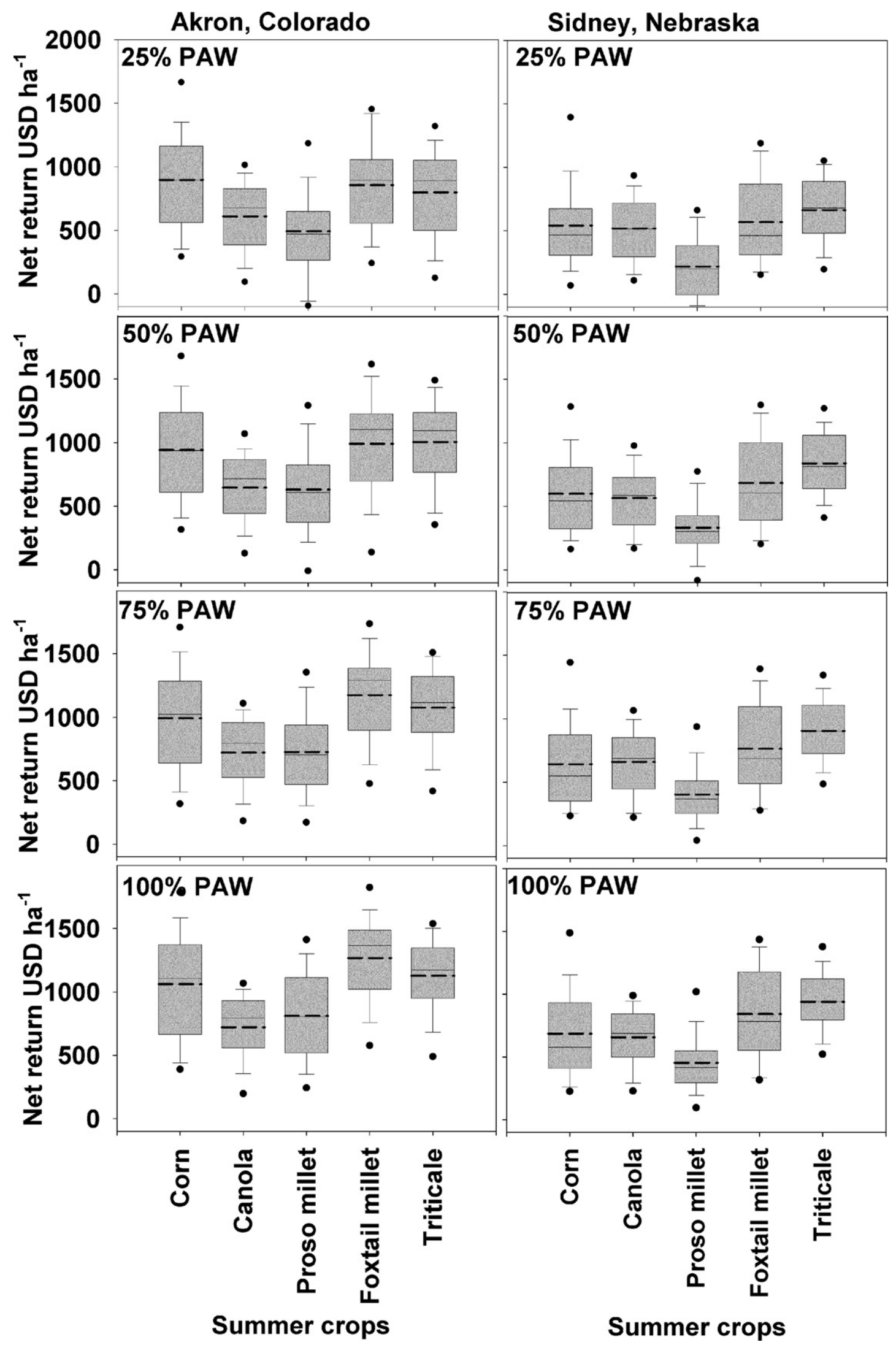

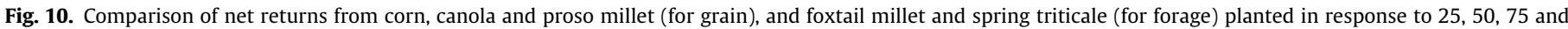

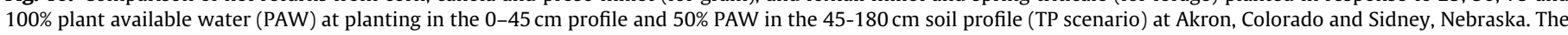

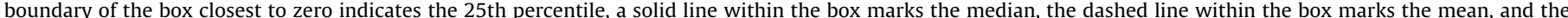

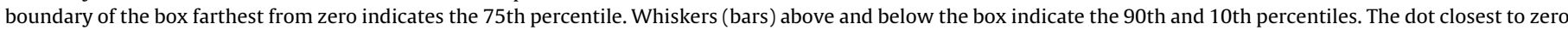

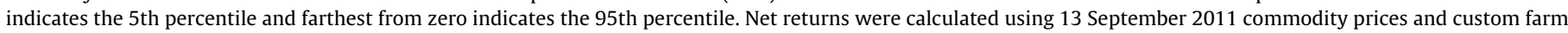
rates from 2006 from northeast Colorado. USD = US dollars. 
net return from crops planted with 25\% PAW at planting at Akron was $\$ 252$ for forage foxtail millet, $\$ 227$ for forage triticale, $\$ 53$ for corn, \$36 for canola, and \$32 for proso millet. When comparing the two forage crops at Akron, foxtail millet gave nearly identical net returns as triticale for 25\% and 50\% PAW, and greater net returns than triticale for $75 \%$ and $100 \%$ PAW. Forage triticale generated greater average net returns than foxtail millet at Sidney under all initial PAW conditions except under the 100\% PAW condition. When considering only the grain crops, net returns averaged over all starting water conditions at Akron were highest for proso millet (\$211) followed by corn (\$185) and then canola (\$136). At Sidney the greatest net returns for the grain crops (averaged over all starting water conditions) were found for canola (\$147) and proso millet (\$115) followed by corn (\$108).

\subsection{Net returns from plantings at various PAW levels in the top profile $(T P)$}

Net returns of all crops except corn increased significantly $(p<0.05)$ with increasing PAW at planting at both Akron and Sidney under the TP scenario. However, the increases with increasing PAW at planting were much less than under the WP scenarios (Fig. 8). Similar to the WP scenario, at 25\% PAW under the TP conditions, all five crops showed negative net dollar returns in some years. At this low $25 \%$ PAW starting water content at Akron, the negative returns were most frequent for proso millet ( $26 \%$ of the time) followed by canola, corn, spring triticale, and foxtail millet. At Sidney the negative returns with $25 \%$ PAW in the TP were most frequent for proso millet ( $48 \%$ of the time) followed by corn ( $45 \%$ ), canola ( $17 \%)$, foxtail millet (1\%), and spring triticale (1\%). Also, when plantings were made with $75 \%$ or $100 \%$ PAW at planting there was a greater than $82 \%$ probability for positive net returns for all crops at both locations except for corn at Sidney where the probability of obtaining a positive net return was 70-75\%. At both Akron and Sidney, average net returns from crops planted in response to all PAW levels at planting were much higher for the forage crops (foxtail millet and triticale) than for the grain crops (corn, canola, and proso millet). Foxtail millet showed similar average net returns as triticale for the 25\%, 50\%, and 75\% PAW levels at planting at Akron. Under the 100\% PAW level at planting at Akron foxtail millet gave higher average net returns than triticale (Fig. 8). At Sidney net returns were slightly higher for triticale than for foxtail millet under all four PAW levels. Under the 25\% PAW at planting condition at Akron the net return was similar for all three grain crops, but the average net return at Sidney was highest for canola. Under the 100\% PAW at planting condition average net return for proso millet at Akron was higher than for corn and canola, while at Sidney under this high starting soil water condition the average net return was highest for canola and lowest for corn with proso millet showing intermediate net returns.

\subsection{Net returns using commodity prices for 13 September 2011}

Prices for grains and forages have recently been much higher than the 10 -yr average prices shown in Table 3 . We recomputed the net returns for all five crops based on prices that could be received for the crops on 13 September 2011 in northeastern Colorado as a "snapshot in time" to see if there were notable differences in the relative crop order of net returns. For both Akron and Sidney under the WP scenario (Fig. 9) forages were still generally more profitable than the grain crops. Corn was clearly the most profitable grain crop at Akron with average net returns under all four starting PAW levels that were very similar to average net returns for foxtail millet. Corn was less profitable at Sidney than at Akron under all four PAW levels, and was the most profitable of the three grain crops. Triticale was more profitable than foxtail millet with 25,50 , and $75 \%$ PAW at planting, but at $100 \%$ PAW foxtail millet was the more profitable forage crop. Similarly under the TP scenario, corn at Akron was more profitable than the other two grain crops, but the forage crops were more profitable than corn at $75 \%$ and $100 \%$ PAW (Fig. 10). At Sidney the higher average profitability of corn was also simulated, and the forages similarly remained more profitable under all four PAW levels than the grain crops. Using the more current higher crop prices mainly had the effect of increasing the overall net profitability of all five crops as well as increasing corn profitability relative to the other crops at both locations.

\section{Conclusions}

At both Akron, Colorado and Sidney, Nebraska in the central Great Plains, USA, simulated grain yields of corn, canola, and proso millet and forage yields of foxtail millet and triticale increased as PAW at planting increased, especially when PAW changes were considered for the whole soil profile. When the five crops considered here were planted under similar initial PAW conditions, they differed in yield and economic returns due not only to price differences of their harvest products but also to differences in harvest yields resulting from differences in growing season lengths and associated precipitation received. Greater net returns were found for the two forage crops than for the three grain crops. The data and figures generated in this study can be used to estimate relative crop yields, net returns, and risk involved in selecting one of the five studied spring- or summer-planted crops to intensify the WF system into, potentially, a winter wheat-spring/summer cropfallow rotation, when a measure or estimate of the PAW at planting is available. Intensifying the wheat-fallow system to two crops in three years is not likely to greatly influence wheat yields following the production of the spring or summer crop, as the 12-14-month fallow period prior to wheat planting allows for significant recharge of soil water. Nielsen et al. (2002) showed 9-yr average soil water contents at wheat planting and wheat yields that were the same for both wheat-fallow and wheat-corn-fallow no-till production systems. However, farmers would need to be aware of the fact that changes in net returns are likely to occur when intensifying from a wheat-fallow system to a three-year rotation where a crop is planted in the growing season following wheat production. These changes in net returns will be a result of the productivity and expenses associated with producing both crops in the system rather than from any of the individual crops involved (wheat or the summer crop) (Peterson et al., 1993, 1996; Halvorson et al., 2002; Peterson and Westfall, 2004).

\section{References}

Acosta-Martınez, V., Mikha, M.M., Vigil, M.F., 2007. Microbial communities and enzyme activities in soils under alternative crop rotations compared to wheat-fallow for the Central Great Plains. Applied Ecology 37, 41-52.

Ahuja, L.R., Rojas, K.W., Hanson, J.D., Shafer, M.J., Ma, L. (Eds.), 2000. Root Zone Water Quality Model. Modeling Management Effects on Water Quality and Crop Production. Water Resources Publications, LLC, Highlands Ranch, CO.

Anderson, R.L., 1998. Designing rotations for a semiarid region. In: Proc. 10th Annual Colorado Conserv. Tillage Assoc., Meeting, Sterling, CO, 3-4 February 1998. Colorado Conserv. Tillage Assoc., Sterling, pp. 4-15.

Anderson, R.L., Bowman, R.A., Nielsen, D.C., Vigil, M.F., Aiken, R.M., Benjamin, J.G., 1999. Alternative crop rotations for the central Great Plains. Journal of Production Agriculture 12, 95-99.

Black, A.L., 1983. Cropping practices: Northern Great Plains. In: Dregne, E., Willis, W.O. (Eds.), Dryland Agriculture. Agron. Monogr. 23. ASA, CSSA, SSSA, Madison, WI, pp. 398-406.

Bowman, R.A., Reeder, J.D., Lover, L.W., 1990. Changes in soil properties after 3, 20 , and 60 years of cultivation. Soil Science 150, 851-857.

Bowman, R.A., Vigil, M.F., Nielsen, D.C., Anderson, R.L., 1999. Soil organic matter changes in intensively cropped dryland systems. Soil Science Society of America Journal 63, 186-191.

Delgado, J.A., Follett, R.F., Shaffer, M.J., 2000. Simulation of nitrate-nitrogen dynamics for cropping systems with different rooting depths. Soil Science Society of America Journal 64, 1050-1054. 
Dhuyvetter, K.C., Thompson, C.R., Norwood, C.A., Halvorson, A.D., 1996. Economics of dryland cropping systems in the Great Plains: a review. Journal of Production Agriculture 9, 216-222.

Dowdy, S., Wearden, S., 1991. Statistics for Research, 2nd ed. John Wiley \& sons, New York, p. 629

Edwards, W., 2007. Iowa farm custom rate survey. Ag Decision Maker File A3-10. Iowa State University, Ames. Available on line at <http://www.extension.iastate.edu/NR/rdonlyres/FD84BED8-516D-4FAA9DD2-4F12F8ABECB8/51766/2007CustomRate.pdf> (verified 8/25/2010).

Elliott, E.T., Cole, C.V., 1989. A perspective on agroecosystem science. Ecology 70 , 1597-1602.

Felter, D.G., Lyon, D.J., Nielsen, D.C., 2006. Evaluating crops for a flexible summer fallow cropping system. Agronomy Journal 98, 1510-1517.

Fisher, R.A., Turner, N.C., 1978. Plant productivity in the arid and semiarid zones. Annual Review of Plant Physiology 29, 277-317.

Greb, B.W., 1979. Reducing Drought Effects on Cropland in the West-central Great Plains. USDA Info. Bull. No. 420. U.S. Gov. Printing Office, Washington, DC, p. 20402.

Halvorson, A.D., 1990. Cropping systems and $\mathrm{N}$ fertilization for efficient water use in the Central Great Plains. Great Plains Agricultural Council Bulletin 131, 117-123.

Halvorson, A.D., Peterson, G.A., Reule, C.A., 2002. Tillage system and crop rotation effects on dryland crop yields and soil carbon in the Central Great Plains. Agronomy Journal 94, 1429-1436.

Hanks, R.J., 1983. Yield and water-use relationships: an overview. In: Taylor, H.M., Jordan, W.R., Sinclair, T.R. (Eds.), Limitations to Efficient Water Use in Crop Production. American Society of Agronomy, Madison, WI, USA, pp. 393-410.

Hoogenboom, G., Wilkens, P.W., Tsuji, G.Y., 1999. Decision Support System for Agrotechnology Transfer (DSSAT) v.3, vol. 4. University of Hawaii, Honolulu

Jame, Y.W., Cutforth, H.W., 1996. Crop growth models for decision support systems. Canadian Journal of Plant Science 76, 9-19.

Jones, J.W., Hoogenboom, G., Porter, C.H., Boote, K.J., Batchelor, W.D., Hunt, L.A., Wilkens, P.W., Singh, U., Gijsman, A.J., Ritchie, J.T., 2003. The DSSAT cropping system model. European Journal of Agronomy 18, 235-265.

Lyon, D.J., Baltensperger, D.D., Blumenthal, J.M., Burgener, P.A., Harveson, R.M., 2004. Eliminating summer fallow reduces winter wheat yields, but not necessarily system profitability. Crop Science 44, 855-860.

Lyon, D.J., Boa, F., Arkebauer, T.J., 1995. Water-yield relations of several springplanted dryland corps following winter wheat. Journal of Production Agriculture 8, 281-286.

Lyon, D.J., Nielsen, D.C., Felter, D.G., Burgener, P.A., 2007. Choice of summer fallow replacement crop impacts subsequent winter wheat. Agronomy Journal 99, 578-584.

Ma, L., Hoogenboom, G., Ahuja, L.R., Ascough II, J.C., Saseendran, S.A., 2006. Evaluation of the RZWQM-CERES-Maize hybrid model for maize production. Agricultural Systems 87, 274-295.

Ma, L., Hoogenboom, G., Ahuja, L.R., Nielsen, D.C., Ascough II, J.C., 2005. Evaluation of the RZWQM-CROPGRO hybrid model for soybean production. Agronomy Journal 97, 1172-1182.

Ma, L., Hoogenboom, G., Saseendran, S.A., Bartling, P.N.S., Ahuja, L.R., Green, T.R. 2009. Estimates of soil hydraulic properties and root growth factor on soil water balance and crop production. Agronomy Journal 101, 572-583.

Ma, L., Nielsen, D.C., Ahuja, L.R., Malone, R.W., Saseendran, S.A., Rojas, K.W., Hanson, J.D., Benjamin, J.G., 2003. Evaluation of RZWQM under varying irrigation levels in eastern Colorado. Transactions of the ASAE 46, 39-49.

Mathews, R., Stephens, W., Hess, T., Middleton, T., Graves, A., 2002. Applications of crop/soil simulation models in tropical agricultural systems. Advances in Agronomy 76, 24-31.

Minor, H.C., Meinke, L.J., 1990. Canola production systems in the central US region. In: Proc. International Canola Conf. Atlanta, GA. Potash Phosphate Institute, Atlanta, GA, pp. 261-270.

Nielsen, D.C., 1998. Comparison of three alternative oilseed crops for the central Great Plains. Journal of Production Agriculture 11, 336-341.

Nielsen, D.C., Anderson, R.L., Bowman, R.A., Aiken, R.M., Vigil, M.F., Benjamin, J.G., 1999. Winter wheat and proso millet yield reduction due to sunflower in rotation. Journal of Production Agriculture 12, 193-197.

Nielsen, D.C., Calderón, F.G., 2011. Fallow effects on soil. In: Hatfield, J.L., Sauer, T.J. (Eds.), Soil Management, Building a Stable Base for Agriculture. Am. Soc. of Agron., Soil Sci. Soc. Am., Madison, WI, pp. 287-300.
Nielsen, D.C., Unger, P.W., Miller, P.R., 2005. Efficient water use in dryland cropping systems in the Great Plains. Agronomy Journal 97, 364-372.

Nielsen, D.C., Vigil, M.F., 2005. Legume green fallow effect on soil water content at wheat planting and wheat yield. Agronomy Journal 97, 684-689.

Nielsen, D.C., Vigil, M.F., 2010. Precipitation storage efficiency during fallow in wheat-fallow systems. Agronomy Journal 102, 537-543.

Nielsen, D.C., Vigil, M.F., Anderson, R.L., Bowman, R.A., Benjamin, J.G., Halvorson, A.D., 2002. Cropping system influence on planting water content and yield of winter wheat. Agronomy Journal 94, 962-967.

Nielsen, D.C., Vigil, M.F., Benjamin, J.G., 2006. Forage yield response to water use for dryland corn, millet, and triticale in the Great Plains. Agronomy Journal 98 992-998.

Nielsen, D.C., Vigil, M.F., Benjamin, J.G., 2009. The variable response of dryland corn yield to soil water content at planting. Agricultural Water Management 96, 330-336.

Nielsen, D.C., Vigil, M.F., Benjamin, J.G., 2010. Evaluating decision rules for dryland rotation crop selection. Field Crops Research 120, 254-261.

Norwood, C.A., Schlegel, A.J., Morishita, D.W., Gwin, R.E., 1990. Cropping system and tillage effects on available soil water and yield of grain sorghum and winte wheat. Journal of Production Agriculture 3, 356-362.

Pavlista, A.D., Baltensperger, D.D., 2007. Phenology of oilseed crops for bio-diesel in the High Plains. In: Janick, J., Whipkey, A. (Eds.), Issues in New Crops and New Uses. ASHS Press, Alexandria, VA, pp. 60-63.

Peterson, G.A., Schlegel, A.J., Tanaka, D.L., Jones, O.R., 1996. Precipitation use efficiency as affected by cropping and tillage systems. Journal of Production Agriculture 9, 180-186.

Peterson, G.A., Westfall, D.G., Cole, C.V., 1993. Agro-ecosystem approach to soil and crop management research. Soil Science Society of America Journal 57 1354-1360.

Peterson, G.A., Westfall, D.G., 2004. Managing precipitation use in sustainable dryland agroecosystems. Annals of Applied Biology 144, 127-138.

Richardson, C.W., 1985. Weather simulation for crop management models. Transactions of the ASAE 28,1602-1606.

Saseendran, S.A., Ahuja, L.R., Nielsen, D.C., Trout, T.J., Ma, L., 2008. Use of crop simulation models to evaluate limited irrigation management options for corn in a semiarid environment. Water Resources Research 44, W00E02, http://dx.doi.org/10.1029/2007WR006181.

Saseendran, S.A., Ma, L., Nielsen, D.C., Vigil, M.F., Ahuja, L.R., 2005a. Simulating planting date effects on corn production using RZWQM and CERES-Maize. Agronomy Journal 97, 58-71.

Saseendran, S.A., Nielsen, D.C., Lyon, D.J., Ma, L., Felter, D.G., Baltensperger, D.D. Hoogenboom, G., Ahuja, L.R., 2009. Modeling responses of dryland spring triticale, proso millet and foxtail millet to initial soil water in the High Plains. Field Crops Research 10, 48-63.

Saseendran, S.A., Nielsen, D.C., Ma, L., Ahuja, L.R., 2010a. RZWOM2 simulations of alternative cropping systems with and without summer crops in the Central Great Plains. Agronomy Journal 102, 1521-1534.

Saseendran, S.A., Nielsen, D.C., Ma, L., Ahuja, L.R., 2010b. Adapting CROPGRO for simulating canola growth in RZWQM2 and DSSAT. Agronomy Journal 102 1606-1621.

Saseendran, S.A., Nielsen, D.C., Ma, L., Ahuja, L.R., Halvorson, A.D., 2004. Modeling nitrogen management effects on winter wheat production using RZWQM and CERES-wheat. Agronomy Journal 96, 615-630.

Saseendran, S.A., Nielsen, D.C., Ma, L., Ahuja, L.R., Vigil, M.F., Halvorson, A.D., 2005b. Effectiveness of RZWQM for simulating alternative Great Plains cropping systems. Agronomy Journal 97, 1183-1193.

Shanahan, J.F., Anderson, R.L., Greb, B.W., 1988. Productivity and water use of proso millet grown under three crop rotations in the central Great Plains. Agronomy Journal 80, 487-492.

Tanaka, D.L., Anderson, R.L., 1997. Soil water storage in conservation tillage systems. Journal of Soil and Water Conservation 52, 363-367.

Vigil, M.F., Nielsen, D.C., 1998. Winter wheat yield depression from legume green fallow. Agronomy Journal 90, 727-734.

Weisensel, W.P., Van Kooten, G.C., Schoney, R.A., 1991. Relative riskiness of fixed vs. flexible crop rotations in the dryland cropping region of western Canada'. Agribusiness 7, 551-562. 